\title{
The antagonistic and synergistic effects of temperature during solar disinfection of synthetic secondary effluent
}

\author{
Stefanos Giannakis ${ }^{1,2,3}$, Efthymios Darakas ${ }^{1}$, Antoni Escalas-Cañellas $^{2,4}$, César \\ Pulgarin $^{3, *}$ \\ ${ }^{1}$ Laboratory of Environmental Engineering and Planning, Department of Civil Engineering, Aristotle University of \\ Thessaloniki, 54624 Thessaloniki, Greece \\ ${ }^{2}$ Laboratory of Control of Environmental Contamination, Institute of Textile Research and Industrial Cooperation \\ of Terrassa (INTEXTER), Universitat Politècnica de Catalunya, Colom 15, 08222 Terrassa, Catalonia, Spain \\ ${ }^{3}$ Swiss Federal Institute of Technology, Lausanne, Institute of Chemical Sciences and Engineering, 1015 \\ Lausanne, Switzerland \\ ${ }^{4}$ Department of Chemical Engineering \& Terrassa School of Engineering, Universitat Politècnica de Catalunya, \\ Colom 1, 08222, Terrassa, Catalonia, Spain
}

*Corresponding author: César Pulgarin, Tel: +41216934720; Fax: +41216936161; E-mail: cesar.pulgarin@epfl.ch

\begin{abstract}
A 4-factor, multilevel, full factorial design of 240 experiments was performed in order to investigate the effect of temperature on the inactivation efficiency of spiked Escherichia coli in simulated solar disinfection of a synthetic secondary effluent. The initial population of the microorganisms was $10^{3}, 10^{4}, 10^{5}$ and $10^{6} \mathrm{CFU} / \mathrm{mL}$, the exposure time $1,2,3$ and $4 \mathrm{~h}$, the treatment temperature $20,30,40,50$ and $60^{\circ} \mathrm{C}$ and the sunlight intensity 0,800 and 1200 $\mathrm{W} / \mathrm{m}^{2}$. Radical changes in bacterial behavior, process efficiency and remaining populations were observed, while treating effluents in discreet temperatures. Elevating treatment temperature from 20 to $40^{\circ} \mathrm{C}$ drastically impaired disinfection. Thermal inactivation with no regrowth predominated at $50^{\circ} \mathrm{C}$ and total inactivation of microorganisms was observed at $60^{\circ} \mathrm{C}$ in non-irradiated samples. Irradiation at 800 and $1200 \mathrm{~W} / \mathrm{m}^{2}$ much increased inactivation efficiency, especially at 50 and $60^{\circ} \mathrm{C}$, proving sensitive light-temperature synergy at those temperatures. Total inactivation was achieved within 4 hours under a range of treatment conditions, including all samples at $1200 \mathrm{~W} / \mathrm{m}^{2}$, or $60^{\circ} \mathrm{C}$ samples at $800 \mathrm{~W} / \mathrm{m}^{2}$. Also, $99.9-100 \%$ efficiencies and final population below $1000 \mathrm{CFU} / 100 \mathrm{~mL}$ were obtained at $800 \mathrm{~W} / \mathrm{m}^{2}$ and temperatures of $50^{\circ} \mathrm{C}$ and above. Treatment time, temperature and intensity are the critical parameters for the disinfection process, while initial population is insignificant for removal efficiency. An explanation of the mechanism of the process as well as a general linear model predicting the outcome of the experiments are also suggested.
\end{abstract}


Keywords: Solar disinfection; wastewater; full factorial design; E. coli; modeling 


\section{Research Highlights:}

- We simulated solar disinfection of secondary effluent under controlled conditions.

- A Design of Experiments was implemented on an intensive poly-parametric study.

- The effects of time, temperature, intensity and initial population were evaluated.

- Temperature alters the disinfection kinetics in a dual, non-proportional manner.

- A temperature-dependent model was proposed to describe solar wastewater disinfection.

\section{Graphical Abstract:}

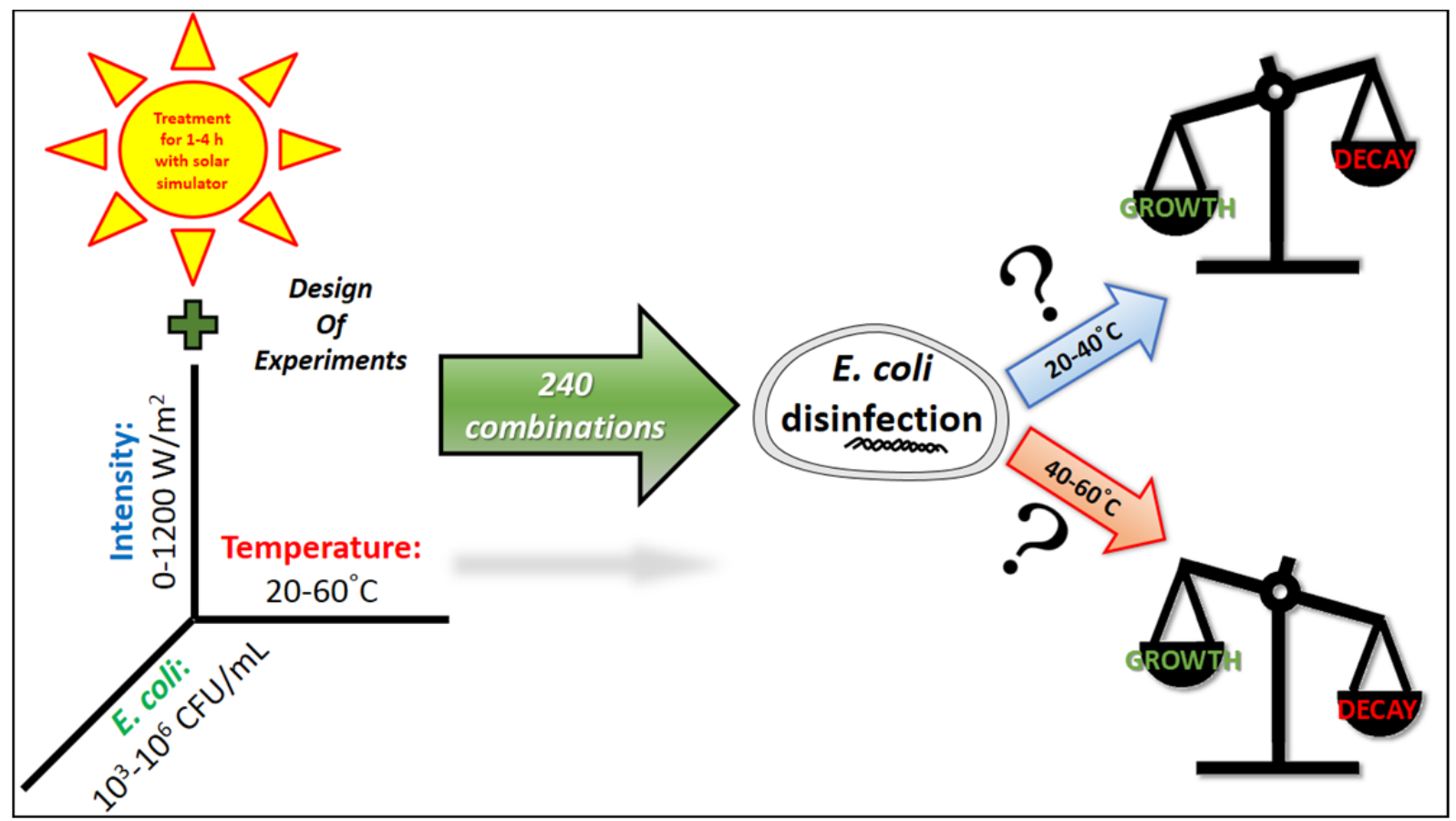




\section{INTRODUCTION}

The scientific basis of solar disinfection was established in the 80's by Acra et al (1984), marking an era of important advances in solar water purification. Gradually, the laboratory work was implemented in the field, with studies performed by Wegelin et al (1994) or McGuigan et al (1998), which set the milestones for solar disinfection (SODIS) of water. More specific studies have followed throughout the years, which highlighted the important parameters of the process, as the UV-A dose, boosting efficacy and rendering SODIS a safe practice (Rincon and Pulgarin, 2004a; Boyle et al., 2008; Ubomba-Jaswa et al., 2009), by explaining the acute inactivation of microorganisms after a few hours of exposure to sunlight.

In parallel, many studies have initiated a cycle of investigations over the efficacy of solar disinfection for wastewater. This field was relatively unexplored and several aspects needed to be studied; this knowledge area welcomed works conducted by Kositzi (2004) and PoloLopez (2012) and Rizzo (2014), that have investigated several aspects of solar photolytic and photocatalytic treatment in different microorganisms (E. coli, Fusarium). Interest was also given in the enhancement of the process by technical means, such as compound parabolic collector (CPC) solar photo-reactors (Polo-Lopez, 2011; Bichai et al., 2012), with special focus given to the application and reuse of wastewater.

Although an interesting practice, there hasn't been enough focus on the possibility of treating wastewater exclusively with sunlight. Works that have demonstrated potential application margins, such as Davies-Colley et al. (1999) and Craggs et al. (2004) in waste stabilization ponds, have indicated the efficiency of sunlight in disinfecting wastewater as well. However, the high retention times make them less attractive than catalytic processes as far as the application point of view is concerned. However, developing countries benefited a lot from SODIS and can possibly benefit from solar disinfection of wastewater. Sanitation conditions in many African countries are marginally non-existent and untreated or poorly treated sewage end up polluting the drinking water supplies (Mwabi et al., 2011). It also occurs that the prementioned regions are areas with a vast number of sunny days per year, so an application of the disinfecting action of light without other technological means could be attractive.

Solar wastewater disinfection follows the same principles as water disinfection; the effect of light against pathogens is the same, but practically, one of the major differences lies in the support microorganisms find in this water matrix. The presence of ions and nutrients, organic matter etc. provide solid ground for their survival and growth (Marugan et al., 2010). The process depends on several parameters, which complicate the study more than the drinking water one. Another important aspect is the temperature conditions that are present during the 
treatment. SODIS applications have reported elevated temperatures and synergistic actions of light and UV (Wegelin et al., 1994; McGuigan et al, 1998), in otherwise simpler water matrices. Reed et al. (2004) highlighted, among others, the presence of organic substances in SODIS water; the case of wastewater is an even enhanced one.

Hence, since the number of examined parameters is high, it is useful to employ experimental design techniques, which permit the extraction of information otherwise not visible (Montgomery, 2001). This tool has been proven efficient in works that study wastewater disinfection (Mosteo et al., 2006; Rodrigues-Chueca et al., 2012), by creating a pre-designed set of experiments, which explains the process and the interactions between the studied parameters.

Under this prism, the current work focuses on the disinfection of wastewater by solar light alone and a statistical approach has been done, to investigate the behavior of microorganisms in synthetic secondary wastewater, when exposed to sunlight. In summary, a full factorial design has been employed to further investigate the effects of i) exposure time, ii) treatment temperature, iii) initial bacterial population and iv) sunlight intensity on E. coli, in batch tests, simulating solar disinfection of secondary treated wastewater. The efficiency of the process was measured, as well as a construction of a general linear model, working as an indicator of the process efficiency. 


\section{MATERIALS AND METHODS}

\subsection{Preparation of the synthetic secondary effluent}

The pre-experimental processes involved with the preparation of the synthetic wastewater included two significant parts: the preparation of the E. coli suspension and the actual wastewater, performed as follows.

\begin{tabular}{|rl|rl|}
\hline \multicolumn{4}{|c|}{ Nomenclature } \\
\hline $\boldsymbol{C F U}$ & Colony Forming Units & $\boldsymbol{P}$ & P-value \\
\hline $\boldsymbol{W}$ & Watts & $\boldsymbol{t}$ & Treatment time \\
\hline $\boldsymbol{D O E}$ & Design of Experiments & $\boldsymbol{T}$ & Temperature \\
\hline $\boldsymbol{S S}$ & Sum of Squares & $\boldsymbol{I}$ & Light Intensity \\
\hline $\boldsymbol{S e q} \boldsymbol{S S}$ & Sequential Sum of Squares & $\boldsymbol{S}$ & Standard Error of the Regression \\
\hline $\boldsymbol{A d j} \boldsymbol{S S}$ & Adjusted Sum of Squares & $\boldsymbol{P R E S S}$ & Prediction Sum of Squares \\
\hline $\boldsymbol{D F}$ & Degrees of Freedom & $\boldsymbol{R}-\boldsymbol{S q}$ & Sum of Squared Residuals \\
\hline $\boldsymbol{C i}$ & Concentration (at time=i) & $\boldsymbol{R}$-Sq(adj) & Adjusted Sum of Squared Residuals \\
\hline $\boldsymbol{I o g}_{\mathbf{1 0}} \boldsymbol{U}$ & logarithmic Units & $\boldsymbol{R}$-Sq(pred) & Predicted Sum of Squared Residuals \\
\hline $\boldsymbol{F}$ & F-test & & \\
\hline
\end{tabular}

\subsubsection{Preparation of the bacterial cultures}

The selected microorganism was an E. coli K12 strain (MG 1655) and was provided from "Deutsche Sammlung von Mikroorganismen und Zellkulturen". Pre-cultures supplied a colony intended for loop-inoculation in sterile Luria-Bertani broth (10 g Bacto ${ }^{\mathrm{TM}}$ Tryptone, 5 $\mathrm{g}$ Yeast extract, and $10 \mathrm{~g} \mathrm{NaCl}$, per liter of distilled water). After incubation overnight and collection in the stationary phase, bacteria were washed three times, by centrifugation at 5000 $\mathrm{rpm}$, with a neutral $\mathrm{pH}$ pre-sterilized saline solution, containing $8 \mathrm{~g} / \mathrm{L} \mathrm{NaCl}$ and $0.8 \mathrm{~g} / \mathrm{L} \mathrm{KCl}$. The result was a bacterial suspension of $10^{9} \mathrm{CFU} / \mathrm{mL}$, approximately.

\subsubsection{Composition of the synthetic wastewater}

The wastewater employed was described analytically elsewhere (Giannakis et al., 2013). The preparation of the synthetic wastewater took place as follows: $160 \mathrm{mg} / \mathrm{L}$ peptone, $110 \mathrm{mg} / \mathrm{L}$ meat extract, $30 \mathrm{mg} / \mathrm{L}$ urea, $28 \mathrm{mg} / \mathrm{L} \mathrm{K}_{2} \mathrm{HPO}_{4}, 7 \mathrm{mg} / \mathrm{L} \mathrm{NaCl}, 4 \mathrm{mg} / \mathrm{L} \mathrm{CaCl}{ }_{2} \cdot 2 \mathrm{H}_{2} \mathrm{O}$ and $2 \mathrm{mg} / \mathrm{L}$ 
$\mathrm{Mg}_{2} \mathrm{SO}_{4} \cdot 7 \mathrm{H}_{2} \mathrm{O}$. The initial COD was $250 \mathrm{mg} / \mathrm{L}$ COD. In order to better approximate the values of secondary effluent, a 10\% dilution was used (Velez-Colmenares et al, 2011). $1 \mathrm{~mL}$ of concentrated $\left(10^{9}\right)$ bacterial solution per liter was dispersed in the solution, to reach an initial population of $10^{6} \mathrm{CFU} / \mathrm{mL}$. Consecutive dilutions were done to achieve the lower initial populations.

\subsection{Simulated solar light specifications}

The light source was a bench-scale Suntest solar simulator from Hanau, employing a $1500 \mathrm{~W}$ air-cooled Xenon lamp, with effective illumination surface of $560 \mathrm{~cm}^{2}$. A portion of $0.5 \%$ of the emitted photons fall within a range shorter than $300 \mathrm{~nm}$ (UVB) and 7\% in the UVA area (320-400 nm). After $400 \mathrm{~nm}$, the emission spectrum follows the solar spectrum. The solar simulator also contains an uncoated quartz glass light tube and cut-off filters for UVC and IR wavelengths. The three intensity levels employed in this study $(0,800$ and $1200 \mathrm{~W})$ were monitored by a Global and UV radiometer (Kipp \& Zonen Mod. CM3 and CUV3). Concerning the applied intensities, $800 \mathrm{~W} / \mathrm{m}^{2}$ is a feasible value of solar irradiance, in the areas candidate for solar disinfection, in general. On the other hand, $1200 \mathrm{~W} / \mathrm{m}^{2}$ is a relatively high value chosen in purpose, defining i) a neighboring value to the highest intensity able to reach earth's crust and ii) a value with profound results, in order to stress the modifications in bacterial kinetics; our investigations (data not shown) indicated that values around $1000 \mathrm{~W} / \mathrm{m}^{2}$ had the desired effect, but not as obvious as the presented ones.

\subsection{Reactor configuration}

The batch tests that withheld the bacterial samples were cylindrical double-wall Pyrex glass bottle reactors (outer diameter $7.5 \mathrm{~cm}$, inner diameter $6.5 \mathrm{~cm}$, height $9 \mathrm{~cm}$, irradiation surface $20.41 \mathrm{~cm}^{2}$ ), which allow control of the temperature and UVB transmission, as well as mild stirring with magnetic stirrer. Water was taken from the body of the irradiated sample, still under stirring. 


\subsection{Bacterial enumeration}

Bacterial colonies were enumerated by the pour-plating method on 9-cm petri dishes containing PCA agar. Samples were properly diluted to maintain measurable counts on the Petri dishes (15-150 colonies per plate). The detection limit for diluted samples is $10 \mathrm{CFU} / \mathrm{ml}$, and $1 \mathrm{CFU} / \mathrm{mL}$ for the undiluted (Rincon and Pulgarin, 2004b). In all cases, even under 15 colonies per dish, the actual reading of $\mathrm{CFU} / \mathrm{mL}$ is reported here. In each measurement, plating was done in duplicates, and 5\% difference (maximum $10 \%$ in low numbers) was obtained. Therefore, for clarity, error bars of the average counts will not be plotted.

\subsection{Design of Experiments (DOE) set-up}

Full factorial DOE was chosen to investigate the influence of the important parameters of treatment time, temperature and initial bacterial population, on the disinfection process and their possible synergies and/or interactions. When a full factorial DOE is chosen, the responses are measured at all the combinations in the different experimental levels. Combining the different factor levels reflects the conditions in which the various responses are measured by the actual experiments. It was chosen over fractional factorial design to prevent confounding and data credibility loss. Table 1 presents the parameters under study and their respective levels.

MINITAB for Windows was used for the data analysis. The DOE was configured as a Multilevel Full Factorial Design, because of the different levels within the parameters. The timespan of the experiment is $4 \mathrm{~h}$, initial bacterial population was chosen to vary from $10^{3}$ to $10^{6} \mathrm{CFU} / \mathrm{mL}$ and temperature was analyzed for five levels, from 20 to $60^{\circ} \mathrm{C}$. Data analyses are presented grouped by light intensity levels: i) $0 \mathrm{~W}$, ii) $800 \mathrm{~W}$ and iii) $1200 \mathrm{~W}$. Table 2 summarizes the DOE for each intensity level. In our work, temperature and irradiation were varied in order to obtain a range of conditions. Some of the conditions tested are hardly feasible in natural conditions, but achievable, for instance, with mechanical assistance by CPCs or solar collectors. The experimental set-up allowed controlling the temperature at desired levels. The point of this study was to investigate the potential synergies and antagonistic effects that temperature would create and influence, during solar disinfection. In any case, with this method of artificial temperature control, we expect to observe the possible combined effects, positive or negative, according to the potential acquired temperatures in a solar disinfection application. 
Also, MINITAB was used to display both the sequential sums of squares (Seq SS) and adjusted sums of squares (Adj SS), after the presentation of the Degrees of Freedom (DF). Since the model is orthogonal and does not contain covariates, these two SS values will be the same. The SS quantifies the variability between the groups of interest, here being the values of the first column, the control variable (Process efficiency \%). In other words, the difference between the source means and the grand mean is represented. Variation between individual scores and the mean of every group is presented by the values; the greater this value is, the bigger the effect of changing that factor on our control variable is. 


\section{RESULTS}

\subsection{Dark experiments $\left(0 \mathrm{~W} / \mathrm{m}^{2}\right)$ - Effects of reaction time, temperature and initial population in absence of light}

Figure 1a presents the evolution of bacterial population over time, within the varying initial population and the corresponding temperature conditions. The figure can be split into two major groups of curves showing clearly different behavior and their respective sub-groups: i) for temperatures $20-40^{\circ} \mathrm{C}$ and ii) $50-60^{\circ} \mathrm{C}$. In absence of light, the driving force of the reaction is temperature alone. The initial bacterial population sets the bar from which we observe the initiation of the thermal impact. The contour plot of the removal (figure $1 \mathrm{~b}, \%$ Process Efficiency) over time and provides an overview with a clear ineffective area $\left(20-40^{\circ} \mathrm{C}\right)$ and a thermal effect one. However, the main effects plot (figure 1c) does not clearly present the effect of the different temperature ranges and provide a false, rather masked image by the overall means; time for instance seems to be biased by the different efficiencies noticed in figures $1 \mathrm{a}$ and $1 \mathrm{~b}$ and presents quite mild influence in the process, which is not true. Therefore, the graphs are presented divided according to the temperature range they belong, in figure 2 .

For the first group of graphs, in figure $2 \mathrm{a}\left(20-40^{\circ} \mathrm{C}\right)$, it can be noticed that there is a slight increase in the bacterial count. The water matrix supporting the bacterial population is synthetic wastewater and, due to the existing nutrient sources, growth is expected. This observation is valid for all initial bacterial levels and within this increase, there are two tendencies present: Firstly, there is a correlation between the temperature of the reaction and the final bacterial numbers. The $40^{\circ} \mathrm{C}$ traces are always higher than the $30^{\circ} \mathrm{C}$ traces and them, always higher than the $20^{\circ} \mathrm{C}$ traces. This behavior agrees with the fundamental findings of Johnson and Levin (1946) that attribute higher cell division rates in higher temperatures. Secondly, there is a statistical observation presented in Table 3 that generally, higher initial numbers lead to larger percentile increases of population, when the critical temperature is reached.

This behavior changes radically above $40^{\circ} \mathrm{C}$. In the same table (Table 3), we observe that the curves indicate bacterial inactivation instead of bacterial growth. E. coli are mesophilic microorganisms, that typically thrive between $20-45^{\circ} \mathrm{C}$ (Fotadar et al., 2005). Above this temperature, there is a thermal stress applied to the cells, altering the cell wall plus damaging the proteins and nucleic acids, leading to easier bacterial death (Baustein et al., 2013). This 
effect becomes more visible (figure $2 \mathrm{~b}$ ) as we increase the temperature from $50^{\circ} \mathrm{C}$ to $60^{\circ} \mathrm{C}$. Treating E. coli within high temperatures can result to total inactivation as it can be seen for low initial populations, but slightly more difficult when the initial population is high. Also, we observe that temperatures as high as $60^{\circ} \mathrm{C}$ lead to fast inactivation. This is attributable to the increased degradation of the vital components of the cell, by the decomposition mechanisms characterized many decades ago (Johnson and Levin, 1946; Marr and Ingraham, 1962).

As far as the efficiency of the process is concerned, in terms of removal percentage, we notice the variation in figure $2 \mathrm{c}$, which demonstrates the modification of the process, when temperature is increased from 40 to $60^{\circ} \mathrm{C}$. We observe that maximum efficiency is achieved at $60^{\circ} \mathrm{C}$ after $1 \mathrm{~h}$ and as the time passes, the thermal threshold is lower, reaching $51^{\circ} \mathrm{C}$, for a $4-\mathrm{h}$ period of treatment. An increase of $10^{\circ} \mathrm{C}$ achieves dramatic enhancement in removal rates (up to $75 \%$ ) and the last $10^{\circ} \mathrm{C}$ increase ensures total inactivation (figure $2 \mathrm{~d}$ ). The significance of temperature is verified by the $\mathrm{P}$ values of the ANOVA table (Table 5) produced by all data from MINITAB, which validates the previous results; in order of significance, temperature is the most important factor that influences the outcome, then treatment time, while the initial population is the least significant among the three.

\section{2. $800-\mathrm{W} / \mathrm{m}^{2}$ experiments - Effects of reaction time, temperature and initial population for intensity of $800 \mathrm{~W} / \mathrm{m}^{2}$}

The second group of experiments utilizes solar energy to inactivate $E$. coli, with the irradiance of the solar simulator set at $800 \mathrm{~W} / \mathrm{m}^{2}$. The same batch test configurations were used as the control experiments, to ensure comparability among the conditions. Many authors have demonstrated that there is a synergistic action between light and temperature in different media and microorganisms (Wegelin et al., 1994; Petin et al., 1997; McGuigan et al., 1998; Rincon and Pulgarin, 2004). This test investigates the light-temperature interaction in synthetic secondary effluent.

Figure 3a demonstrates in overall the evolution of bacterial population over time, grouped by initial numbers and temperature of the process. Within $4 \mathrm{~h}$ of treatment, samples that were processed at $20^{\circ} \mathrm{C}$ demonstrated a continuous decrease of the population. However, as temperature rises to $30^{\circ} \mathrm{C}$ the remaining populations are somewhat equal or higher than the respective ones at $20^{\circ} \mathrm{C}$. The phenomenon is even clearer at temperatures around $40^{\circ} \mathrm{C}$, where insignificant removal rates are demonstrated and presented in Table 5. Figure $3 \mathrm{~b}$ presents an 
overview of the efficiency of the process, in which we notice a gap, around $40^{\circ} \mathrm{C}$. There is a descending trend until $40^{\circ} \mathrm{C}$ and then an increase in the efficiency, which is verified in figure $3 \mathrm{c}$; temperature is dominating the process and modifies the outcome of the experiment. Therefore, once again we observe the two clear groups of graphs, according to the large temperature groups i) $20-40^{\circ} \mathrm{C}$ and ii) $40-60^{\circ} \mathrm{C}$.

Within this system there are two opposing forces present that determine the outcome so far. Compared to the $0-\mathrm{W} / \mathrm{m}^{2}$ experiments, first of all, (figures $3 \mathrm{a}$ and $4 \mathrm{a}-\mathrm{b}$ ) light changes the growth phenomenon observed before. What appears in figure $3 \mathrm{~b}$ i) as an "island" of low efficiency among the average ones, is attributed to the $40^{\circ} \mathrm{C}$ area, which provides with increased metabolic rates and thereby higher remaining populations. On the one hand, we have the disinfecting action of light, which tends to inactivate bacteria as seen in $20^{\circ} \mathrm{C}$ curves (figure 4a), with the number of inactivated bacteria vs. initial population increasing when initial population is increased. On the other hand, submitting the population to temperatures around $37^{\circ} \mathrm{C}$, in a nutrient-enhanced matrix as the wastewater, mesophiles, such as E. coli, tend to present their highest reproduction rates (Dawes and Sunderland, 1976). E. coli belongs to this category and is encountered in the human gut (Buchanan and Gibbons, 1974), with the normal human body temperatures being the most favorable for their growth. Normally, E. coli are inactivated by exposure to $55^{\circ} \mathrm{C}$ for 1 hour or $60^{\circ} \mathrm{C}$ for 20 minutes (Charkraborty, 1998). Hence, as we raise the temperature in the disinfection process, the two concurrent actions tend to balance in favor of the reproduction rates, around $40^{\circ} \mathrm{C}$.

However, a temperature increase over $45^{\circ} \mathrm{C}$ would affect E. coli metabolic cycles, and lead to cell death. Indeed, as it is observed, the $50^{\circ} \mathrm{C}$ curves (figure $4 \mathrm{~b}$ ) after an initial shoulder, a common observation at solar disinfection processes (Harm, 1980; Sinton et al., 1999; Berney et al., 2006), then present total $\left(10^{3}\right.$ and $10^{4}$ curves $)$ and almost total inactivation $\left(10^{5}\right.$ and $10^{6}$ curves). In addition, we verify that increasing the treatment temperature up to $60^{\circ} \mathrm{C}$ leads to total inactivation of the microorganisms before $60 \mathrm{~min}$, regardless of the initial bacterial population.

Furthermore, one can notice the synergy between light effects and temperature increase at the graphs, by comparing figure 2 with 4 : First of all, at $50^{\circ} \mathrm{C}$ without light, only samples with $10^{3}$ initial population were inactivated, whereas in presence of light $10^{3}$ and $10^{4}$ were totally inactivated and $10^{5}$ and $10^{6}$ presented a 3 or $4 \log _{10} \mathrm{U}$ reduction instead of 1 or $2 \log _{10} \mathrm{U}$. Secondly, $60^{\circ} \mathrm{C}$ treated samples were totally inactivated in less than an hour, slightly faster than in absence of light. Consequently, in the latter case thermal treatment is the main disinfecting force and light is only complementary. 
Speaking in terms of efficiency, figures $4 \mathrm{a}-\mathrm{i}$ and $4 \mathrm{~b}-\mathrm{i}$, provide information about the effect of each parameter over the total inactivation capability of the process. In the $20-40^{\circ} \mathrm{C}$ interval, lower temperatures seem to favor inactivation with the peak appearing between 20 and $25^{\circ} \mathrm{C}$, while treatment time increases the potentials; the $4^{\text {th }}$ hour contributes in the greatest proportion, adding on the inactivation side of the balance. Comparing with the equivalent graphs for $40-60^{\circ} \mathrm{C}$, temperature increase leads to percentile inactivation enhancement, while statistically in both cases, initial bacterial population does not seem to significantly affect the percentage of inactivated bacteria in the process. However, the same actions manage to inactivate lower bacterial numbers more efficiently (in percentage) but in absolute numbers, removal increases with higher populations, due to larger numbers' correspondence of the removal percentage.

Finally, the ANOVA table reveals the important contribution of time and temperature and the milder one from initial bacterial population. The $\mathrm{P}$ values presented in Table 5 are also verified by figures $4 \mathrm{a}-\mathrm{ii}$ ) and $4 \mathrm{~b}$-ii). We draw the information that time almost proportionally increases the total efficiency, while initial population fluctuates around the average inactivated bacteria. What is more important, is the temperature effect on efficiency, which presents what was in detail described before; temperature increase enhances bacterial inactivation, as literature suggested for other water matrices, but only above $40^{\circ} \mathrm{C}$. Otherwise, the disinfection process is delayed by the excessive growth of the microorganisms.

\subsection{High irradiance experiments $\left(1200 \mathrm{~W} / \mathrm{m}^{2}\right)$ - Effects of reaction time, temperature and initial population for high intensity irradiation conditions}

The final experimental part consists of the runs that utilized high intensity illumination. Higher supply of photons in the system could result to higher possibility of effective hits in the $n$ number of crucial areas of the cell, as described by Harm (1980).

Figure 5a presents an overview of the disinfection reactions of the varied initial population. The main and most profound difference between this set-up and the previous ones, is that all samples regardless of initial population and treatment temperature have been inactivated within the time frame of $4 \mathrm{~h}$. The action of light was more intense and influenced the outcome of the experiments in cases that was not sufficient before. Bacteria have now to cope with higher concurrent light and thermal action, which is expressed by less acute kinetics in the final hour. When the samples were treated at lower temperatures, the disinfection curves again present a lag-phase or shoulder, but considerably lower, varying from 30 to $120 \mathrm{~min}$, 
compared to the minimum 3-h shoulder presented under $800 \mathrm{~W} / \mathrm{m}^{2}$ irradiance. Figures $5 \mathrm{~b}$ and c, present once more the erratic behavior around $40^{\circ} \mathrm{C}$, demonstrated as a lower efficiency area (figure 5b) or a mean decrease (figure 5c), however mitigated, compared to the equivalent of $800 \mathrm{~W} / \mathrm{m}^{2}$ or even the increase in numbers observed in null intensity experiments.

What is more, the main effects plot of this high irradiation also add direct information over the main overall efficiency. All parameters concerned, the addition of light initially increased the efficiency from $35 \%$ to $65 \%$ (from 0 to $800 \mathrm{~W} / \mathrm{m}^{2}$ ), to reach $80 \%$ when high intensity is applied. This is a good indicator of the robustness of the system, predicting, at some extent, the success of the group of trials. Finally, it is also shown that the biggest contribution in bacterial inactivation derives from the $1^{\text {st }}$ hour of illumination and the least, but most important from the application point of view, during the $4^{\text {th }}$ hour. Plus, the drop in efficiency around $40^{\circ} \mathrm{C}$ is also visible, like each previous case but less intense; high irradiance illumination compensates for the inactivation difference.

Observing figure $6 \mathrm{a}$, it is clear that, at $1200 \mathrm{~W} / \mathrm{m}^{2}$, the equilibrium between the disinfecting action of light and the growth-stimulating effect of increasing temperatures changes within the $20-40^{\circ} \mathrm{C}$ range. After a $2-3-\mathrm{h}$ shoulder, bacterial numbers fall sharply to total disinfection at the fourth hour. This means the disinfecting action becomes higher than the growth force and, as far as the cell is concerned, indeed, the growth action is present but is no longer in favor of their survival. Also, the contour plot of efficiency over time (figure 6a-i) has a clear area of total inactivation, after $3.5 \mathrm{~h}$, while temperature increase has a mitigated effect of delay in inactivation, compared to all other cases till now.

For higher temperatures, it is shown that at $50^{\circ} \mathrm{C}$, compared to 0 and $800 \mathrm{~W} / \mathrm{m}^{2}$, the same process at $1200 \mathrm{~W} / \mathrm{m}^{2}$ is completed faster, compared with the cases it was completed before, and in total, all cases resolved to total inactivation. As shown in figure 6b, the disinfection kinetics at these particular conditions $\left(1200 \mathrm{~W} / \mathrm{m}^{2}, 50^{\circ} \mathrm{C}\right)$ is very sensitive to the initial bacterial concentration, probably attributable to shielding (Craik et al., 2001) playing a critical role in these runs. At $60^{\circ} \mathrm{C}$ and $1200 \mathrm{~W} / \mathrm{m}^{2}$, complete disinfection is achieved faster than at 0 or $800 \mathrm{~W} / \mathrm{m}^{2}$. Where in absence of light inactivation time was around an hour, at $800 \mathrm{~W} / \mathrm{m}^{2}$ slightly less, and now is even less than 30 minutes. Finally, this outcome is common for all initial populations; all result to total inactivation faster than their respective $800 \mathrm{~W} / \mathrm{m}^{2}$ curves.

The contour plots of the process efficiency (figure 6b-i) indicate clearly the bigger "effective" area of $>99 \%$, and the relatively higher rates; no area lies under $50 \%$ bacterial inactivation even after only $1 \mathrm{~h}$. As treatment time increases the efficiency increases as well, however, the same cannot be observed for temperature. For instance, at $50^{\circ} \mathrm{C}$, only $2.5-3 \mathrm{~h}$ are sufficient to 
achieve total inactivation, demonstrated in figure 6b-ii. Also, from the ANOVA table we draw the information that the efficiency is highly correlated only with treatment time and temperature.

\subsection{Modeling solar disinfection of secondary treated wastewater}

As a result of the statistical interpretation of the experimental data, a simplified model can be proposed. Through the statistical software of MINITAB, a model is suggested, which relates the response factors with the parameters of the process, in order to further analyze the experimental concept, and help facilitate all these experimental runs (Rodrigues-Chueca et al., 2012).

In our experiments, the parameters involved in the process were treatment time, temperature, initial population and light intensity. Furthermore, in order to achieve a decent fitting model, the interactions of the parameters were used; the first-order model $\left(20-60^{\circ} \mathrm{C}\right)$ without interactions yields $\mathrm{R}$-sq $=51.17 \%$ (model not shown). The ANOVA tables have indicated initial population as relatively insignificant; however, we choose to model all the experiments in one equation and include it in the model, expressed as follows:

Process Efficiency $(\%)=-41.60-8.43 \mathrm{t}+1.76 \mathrm{~T}-2.20 \mathrm{e}-005 \mathrm{C}+0.02 \mathrm{I}+0.27 \mathrm{t} * \mathrm{~T}+5.03 \mathrm{e}-$ $006 \mathrm{t} * \mathrm{C}+0.036 \mathrm{t} * \mathrm{I}+3.77 \mathrm{e}-007 \mathrm{~T} * \mathrm{C}-7.26 \mathrm{e}-005 \mathrm{~T} * \mathrm{I}+6.21 \mathrm{e}-009 \mathrm{C} * \mathrm{I}-6.85 \mathrm{e}-008 \mathrm{t}^{*} \mathrm{~T}^{*} \mathrm{C}-$ $0.001 \mathrm{t}^{*} \mathrm{~T} * \mathrm{I}-3.42 \mathrm{e}-010 \mathrm{~T} * \mathrm{C} * \mathrm{I}+4.67 \mathrm{e}-011 \mathrm{t} * \mathrm{~T} * \mathrm{C} * \mathrm{I}$

$S=24.4245, R-S q=65.10 \%, R-S q($ adj $)=62.93 \%, P R E S S=150725, R-S q($ pred $)=60.81 \%$

Figure 7a demonstrates the level of approach. The R-Sq, as a general indicator of the success of the fit, gives a $65 \%$ of match. In addition, we present the coefficients and ANOVA table for the model (Table 6), confirming the small contribution of the initial population to the model. This figure represents the 240 experiments conducted in these conditions and $\mathrm{X}$ axis presents the order of experimental runs, from 1 to 240 . Each $X$ value corresponds to an Efficiency value, shown in $\mathrm{Y}$ axis. The difference between the experimental and the calculated value (linear model values) is shown by the distance among the two corresponding marks. We can see that the trends are similar; the values follow the same tendency and are relatively close.

However, following the same principle noticed in the disinfection experiments, we can propose splitting the data in two sets, of lower and equal to $40^{\circ} \mathrm{C}$ and to higher than $40^{\circ} \mathrm{C}$. 
Even though the use of interactions suggests the introduction of the synergies (especially light and temperature) in the model, we face a possible danger of over-fitting and un-necessary complexity in a simple concept, like the general linear model. For the above reasons, we introduce a temperature-dependent linear model, without the use of interactions between the parameters.

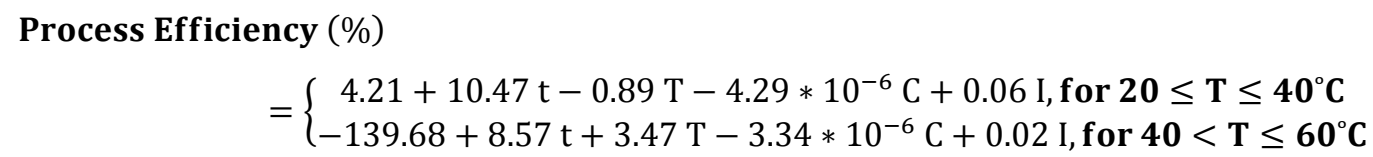

First of all, the coefficients are included in Table 6 . We observe, that the new model has more advantages than the formerly suggested; the regression standard error (S) is lower, it does not use $2^{\text {nd }}$ level interactions and in addition, it yields higher $\mathrm{R}^{2}$ values. Therefore, it is a simpler and more accurate model, describing in better extent the evolution of the process efficiency. Figures $7 \mathrm{~b}$ and $7 \mathrm{c}$ present in separate plots the experimental values acquired versus the predicted ones from the model $\left(40^{\circ} \mathrm{C}\right.$ plotted in both figures for better demonstration of the temperature evolution). All things considered, we suggest that this temperature-dependent model is a good indicator of the tendencies present in solar disinfection of wastewater or an estimating tool concerning the remaining population within some range, rather than an actual predictor of the efficiency. 


\section{DISCUSSION}

\subsection{Inactivation mechanism: Light source and bacterial damage}

Solar disinfection experiments were conducted under a solar simulator that emits all spectrum from $290 \mathrm{~nm}$ and above, excluding infrared wavelengths, due to the existence of cut-off filters. Therefore, the actions expected should be attributed UVB, UVA and visible light.

\subsubsection{UVB irradiation}

Malatana-Surget et al, (2012) have stated the double action of UVB irradiation; in general, UVB damage is considered to mainly cause direct DNA damage, through the creation of photoproducts (cyclobutane pyrimidine dimer and the pyrmidine (6-4) photoproducts) (Hallmich and Gehr, 2010). They also mention the creation of internal and external reactive oxygen species (ROS) such as hydrogen peroxide $\left(\mathrm{H}_{2} \mathrm{O}_{2}\right)$, and more profoundly, the creation of singlet oxygen (Regensburger et al., 2011). These ROS attack nucleic acid, proteins and cell lipids (Storz and Imlay, 1999). However, UVB is very often overlooked, although it has a relatively high contribution in bacterial inactivation. The important impact of UVB inactivation of bacteria has been stated since 1974 (Setlow et al. 1974), there are very few works that add up to this wavelength band to attribute part of the bacterial inactivation. Of course, this happens due to the sensitivity of UVB to meteorological phenomena, but this is far from our case, and we cannot ignore a force two or three orders of magnitude higher than UVA (Opezzo, 2012; Mbonimpa et al, 2012). Also, the peak of UVB germicidal activity, roughly among 300 and $310 \mathrm{~nm}$, is clearly within our range (Mbonimpa et al., 2012) and according to previous reports, UVB radiation of $313 \mathrm{~nm}$ demonstrates an interaction with the $365 \mathrm{~nm}$, to enhance DNA transformation (Peak et al., 1975; Tyrell et al., 1978). Hence, we have a double UVB action, of DNA strand break, and the creation of ROS which have been identified to be implicated in bacterial inactivation through oxidative stress.

\subsubsection{UVA irradiation/near-UV visible light}

UVA-induced loss of bacterial cultivability is attributed to the catalysis of the formation of ROS. It is the least effective irradiation range to damage bacterial DNA directly, but its proven efficiency (Robertson et al., 2005) comes from the biological effects of internal and external ROS attacks, such as protein destruction or adducts of nucleic acid with membrane proteins with the bacterial envelope escaping key damage, towards cell inactivation (Pigeot- 
Remy et al., 2012). One of the first attacks is the respiratory chain and the cell's potential to produce ATP (Bosshard et al., 2010). Other attacks include internal photo-Fenton reaction (Spuhler et al., 2010) due to loose cell iron sources, disruption of normal internal ROS suppression mechanism (SOD, catalase etc.) (Chiang et al., 2012) and others, all related by the ROS production inside and outside the cell. ROS are normal by-products of bacterial respiratory chain, and bacteria possess a big number of suppressive mechanisms (Mishra and Imlay, 2012). Hence, UVA damage is an internal/external oxidative damage, plus the internal/external photo-Fenton contribution, with measurable effects; an increase in dose can inflict greater damage (Polo-Lopez et al, 2011).

\subsection{Inactivation mechanism: Influence of the water matrix}

There is no disagreement that the majority of the solar disinfection experiments were conducted in distilled or drinking water, making the inactivation mechanism clear and well established. The main difference of this synthetic secondary effluent is the added salts and organic components. Marugan et al. (2010) have explained that during bacterial osmotic stress among the first released ions are calcium and magnesium ones, while Caballero et al. (2009) stated the importance of organic substances as nutrient sources for bacteria; therefore, bacterial survival/growth is favored in this matrix. Given the absence of light in the first group of experiments, growth is normal and expected, and as temperature rises, with a peak around $35-39^{\circ} \mathrm{C}$ (according to our discreet choice, $40^{\circ}$ ) growth will be increased. However, this behavior is expected to change when the irradiation is present and light is applied to the sample. The presence of organic substances can induce an indirect stress. They can either be endogenous, like porphyrins, co-enzymes or cytochromes, or exogenous, synthetical ones, which lead to either internal or external photosensitized matter. After receiving UV irradiation, this effect can cause indirect photolysis, while the photo-sensitizers are in an excited, high energetic state (Matthews, 1991; Dunkel, 1992; Reed, 2004). Other works however, have demonstrated reduction of cell inactivation, when inorganic and organic compounds were present (Sichel et al., 2007; Alrousan et al., 2009; Dunlop et al., 2011).

\subsection{Temperature influence and evolution of experiments}

As demonstrated in the experimental part, temperature altered the outcome of the inactivation assays in great extent, from level to level. For this reason, the experiments were divided in 
two parts, below and over $40^{\circ} \mathrm{C}$ degrees. Wegelin et al, (1994) reported no differences between 12 and $40^{\circ} \mathrm{C}$ in water, and Reed (2004) explained this behavior by the double effect of temperature range. When temperature is increased, growth is favored, and inactivation as well: Thermally-driven growth is cancelled by oxygen depletion, due to its lower solubility at higher temperatures. In our case, growth was favored to a point that the synergic effect was cancelled, depletion of oxygen did not occur (samples under mild stirring) and eventually, until the intensity was increased over $1000 \mathrm{~W} / \mathrm{m}^{2}$, light alone could not overcome the rapid growth. Rincon and Pulgarin suggested the increase in intensity to efficiently remove E. coli (Rincon and Pulgarin, 2003), and also, the effects of physiological bacterial state; we adopted the same techniques to ensure reproducible results.

When low temperatures were applied, metabolic activity was at its minimum, so the same actions of light battled against less targets. This, however was not the case in temperatures around $40^{\circ} \mathrm{C}$, were excessive growth was observed, thus providing more targets for incoming photons or ROS. In addition, this excess growth can lead to extensive shielding from one cell to another (Craik et al., 2001), inducing higher inactivation rates for increased populations. In the first steps of each experiment, a shoulder is observed, and this latency effect is due to initial self-defense mechanisms (Rincon and Pulgarin, 2003). As time passes and new generations of bacteria appear due to high reproduction rates, the new generations are more resistant to the disinfecting action of light, having endured the exposure of the original cells towards the actions of light. It has been stated that a greater effectiveness of applying a high intensity for a short time is demonstrated and preferred, rather than applying a lower intensity for a longer period of time (Sommer et al, 1998). 


\section{CONCLUSIONS}

- $\quad$ Non-irradiated samples of synthetic secondary effluent treated at $20-40^{\circ} \mathrm{C}$ showed slight growth during treatment. Significantly, thermal inactivation predominated at $50^{\circ} \mathrm{C}$ and was total at $60^{\circ} \mathrm{C}$.

- Irradiation at $800 \mathrm{~W} / \mathrm{m}^{2}$ was sufficient to suppress growth at $20-40^{\circ} \mathrm{C}$, but not for providing proper disinfection in $4 \mathrm{~h}$ of treatment, with efficiency decreasing with rising temperatures and showing a minimum around $40^{\circ} \mathrm{C}$. Synergy between light and temperature above $40^{\circ} \mathrm{C}$ was evident, with all $60^{\circ} \mathrm{C}$ samples undergoing total disinfection in just $1 \mathrm{~h}$, or, at $50^{\circ} \mathrm{C}$, high disinfection efficiencies after $4 \mathrm{~h}$ of treatment.

- Irradiation at $1200 \mathrm{~W} / \mathrm{m}^{2}$ resulted in total disinfection (no bacterial counts) in $4 \mathrm{~h}(20$ $\left.40^{\circ} \mathrm{C}\right)$, in $1.5-4 \mathrm{~h}\left(50^{\circ} \mathrm{C}\right)$ or in just $0.5 \mathrm{~h}\left(60^{\circ} \mathrm{C}\right)$, showing again the light-temperature synergy.

- The profound actions of UVB and UVA irradiation demonstrated different results, according to the experimental temperature range, with the cases of very low and very high demonstrating the best results, due to either lower metabolic rhythm or synergy between temperature and light, plus thermal modifications of cells' proteins.

- A 4-factor, multilevel, complete factorial design of experiments has proved a powerful, useful tool to evaluate the main variables governing disinfection. A linear model with interactions ( $\mathrm{R}-\mathrm{Sq}=65.1 \%, \mathrm{~S}=24.42)$ has been initially proposed and improved, when it was modified to a temperature dependent one. The new model is simpler (no interactions needed), as well as more accurate $\left(\mathrm{S}=20.0507, \mathrm{R}-\mathrm{Sq}=73.08 \%\right.$, for $20<\mathrm{T} \leq 40^{\circ} \mathrm{C}$ and $\mathrm{S}=$ $21.9270, \mathrm{R}-\mathrm{Sq}=68.41 \%$ for $40<\mathrm{T} \leq 60^{\circ} \mathrm{C}$ ). While unrelated to any fundamental modeling of the process, it has allowed to statistically determine the significant factors and interactions in the process.

- As far as a potential application is concerned, the recommended practice would be to acquire the highest irradiation times possible for the given regional climatological constraints. Given the fact that real applications will be temperature-limited, the design practices should be oriented to acquiring prolonged exposure to sunlight, since we observed that extension of the treatment always favored bacterial disinfection. 


\section{ACKNOWLEDGEMENTS}

The authors wish to thank, in order of acquisition, the Mediterranean Office for Youth Program (MOY, call 2011-2014), by means of which Mr. Stefanos Giannakis has received a PhD mobility grant (MOY grant $\mathrm{N}^{\circ} 2010 / 044 / 01$ ) in the joint Environmental Engineering Doctoral Program. Also would wish to thank the Swiss Government for the Swiss Government Excellence Scholarship, by means of which Mr. Stefanos Giannakis has received a Research Visit fellowship (No. 2012.0499).

\section{REFERENCES}

[1] A. Acra, Z. Raffoul, Y. Karahagopian, Solar disinfection of drinking water and oral rehydration solutions: guidelines fo household application in developing countries, (1984).

[2] D. Alrousan, P.S. Dunlop, T.A. McMurray, J.A. Byrne, Photocatalytic inactivation of E. coli in surface water using immobilised nanoparticle TiO2 films, Water research, 43 (2009) 47-54.

[3] M. Berney, H.U. Weilenmann, A. Simonetti, T. Egli, Efficacy of solar disinfection of Escherichia coli, Shigella flexneri, Salmonella Typhimurium and Vibrio cholerae, Journal of applied microbiology, 101 (2006) 828-836.

[4] F. Bichai, M.I. Polo-López, P. Fernández Ibañez, Solar disinfection of wastewater to reduce contamination of lettuce crops by Escherichia coli in reclaimed water irrigation, Water research, 46 (2012) 6040-6050.

[5] R.A. Blaustein, Y. Pachepsky, R.L. Hill, D.R. Shelton, G. Whelan, Escherichia coli survival in waters: Temperature dependence, Water research, 47 (2013) 569-578.

[6] M. Boyle, C. Sichel, P. Fernández-Ibáñez, G. Arias-Quiroz, M. Iriarte-Puña, A. Mercado, E. Ubomba-Jaswa, K. McGuigan, Bactericidal effect of solar water disinfection under real sunlight conditions, Applied and environmental microbiology, 74 (2008) 2997-3001.

[7] N.D. Levine, Buchanan, R. E. \& Gibbons, N. E., eds. 1974. Bergey's Manual of Determinative Bacteriology. 8th ed. Williams \& Wilkins Co., Baltimore, Md.

[8] L. Caballero, K. Whitehead, N. Allen, J. Verran, Inactivation of Escherichia coli on immobilized TiO2 using fluorescent light, Journal of Photochemistry and Photobiology A: Chemistry, 202 (2009) 92-98.

[9] P. Chakraborty, A Textbook of Microbiology, New Central Book Agency, 2005.

[10] R.J. Craggs, A. Zwart, J.W. Nagels, R.J. Davies-Colley, Modelling sunlight disinfection in a high rate pond, Ecological Engineering, 22 (2004) 113-122.

[11] S.A. Craik, D. Weldon, G.R. Finch, J.R. Bolton, M. Belosevic, Inactivation of cryptosporidium parvum oocysts using medium-and low-pressure ultraviolet radiation, Water research, 35 (2001) 13871398.

[12] R. Davies-Colley, A. Donnison, D. Speed, C. Ross, J.a. Nagels, Inactivation of faecal indicator micro-organisms in waste stabilisation ponds: interactions of environmental factors with sunlight, Water research, 33 (1999) 1220-1230.

[13] I. Dawes, I. Sutherland, Microbial Physiology. Basic Microbiology, in, Blackwell Scientific Publications. Oxford. 185 pages, 1976.

[14] P. Dunlop, M. Ciavola, L. Rizzo, J. Byrne, Inactivation and injury assessment of Escherichia coli during solar and photocatalytic disinfection in LDPE bags, Chemosphere, 85 (2011) 1160-1166.

[15] L. Dünkel, Organic Photochemistry:“A Visual Approach”, Zeitschrift für Physikalische Chemie, 177 (1992) 122-123. 
[16] U. Fotadar, P. Zaveloff, L. Terracio, Growth of Escherichia coli at elevated temperatures, Journal of basic microbiology, 45 (2005) 403-404.

[17] S. Giannakis, A.I. Merino Gamo, E. Darakas, A. Escalas-Cañellas, C. Pulgarin, Impact of different light intermittence regimes on bacteria during simulated solar treatment of secondary effluent: Implications of the inserted dark periods, Solar Energy, 98, Part C (2013) 572-581.

[18] G. Storz, J.A. Imlay, Oxidative stress, Current opinion in microbiology, 2 (1999) 188-194.

[19] C. Hallmich, R. Gehr, Effect of pre-and post-UV disinfection conditions on photoreactivation of fecal coliforms in wastewater effluents, Water research, 44 (2010) 2885-2893.

[20] W. Harm, Biological effects of ultraviolet radiation, Cambridge University Press Cambridge, 1980 .

[21] H. Hernández-García, H. Lopez-Arjona, J.F. Rodríguez, R. Enriquez, Preliminary Study of the Disinfection of Secondary Wastewater Using a Solar Photolytic-Photocatalytic Reactor, Journal of Solar Energy Engineering, 130 (2008) 41004.

[22] F.H. Johnson, I. Lewin, The growth rate of E. coli in relation to temperature, quinine and coenzyme, Journal of Cellular and Comparative Physiology, 28 (1946) 47-75.

[23] M. Kositzi, I. Poulios, S. Malato, J. Cáceres, A. Campos, Solar photocatalytic treatment of synthetic municipal wastewater, Water research, 38 (2004) 1147-1154.

[24] K.G. Lindenauer, J.L. Darby, Ultraviolet disinfection of wastewater: effect of dose on subsequent photoreactivation, Water research, 28 (1994) 805-817.

[25] A.G. Marr, J.L. Ingraham, Effect of temperature on the composition of fatty acids in Escherichia coli, Journal of Bacteriology, 84 (1962) 1260-1267.

[26] J. Marugán, R. van Grieken, C. Pablos, C. Sordo, Analogies and differences between photocatalytic oxidation of chemicals and photocatalytic inactivation of microorganisms, Water research, 44 (2010) 789-796.

[27] S. Matallana-Surget, C. Villette, L. Intertaglia, F. Joux, M. Bourrain, P. Lebaron, Response to UVB radiation and oxidative stress of marine bacteria isolated from South Pacific Ocean and Mediterranean Sea, Journal of Photochemistry and Photobiology B: Biology, (2012).

[28] R. Matthews, Environment: photochemical and photocatalytic processes. Degradation of organic compounds, in: Photochemical conversion and storage of solar energy, Springer, 1991, pp. 427-449.

[29] E.G. Mbonimpa, B. Vadheim, E.R. Blatchley III, Continuous-flow solar UVB disinfection reactor for drinking water, Water research, 46 (2012) 2344-2354.

[30] K. McGuigan, T. Joyce, R. Conroy, J. Gillespie, M. Elmore-Meegan, Solar disinfection of drinking water contained in transparent plastic bottles: characterizing the bacterial inactivation process, Journal of applied microbiology, 84 (1998) 1138-1148.

[31] D.C. Montgomery, Introduction to statistical quality control, (2001). Wiley, New York

[32] R. Mosteo, P. Ormad, E. Mozas, J. Sarasa, J.L. Ovelleiro, Factorial experimental design of winery wastewaters treatment by heterogeneous photo-Fenton process, Water research, 40 (2006) 1561-1568.

[33] J. Mwabi, F. Adeyemo, T. Mahlangu, B. Mamba, B. Brouckaert, C. Swartz, G. Offringa, L. Mpenyana-Monyatsi, M. Momba, Household water treatment systems: a solution to the production of safe drinking water by the low-income communities of Southern Africa, Physics and Chemistry of the Earth, Parts A/B/C, 36 (2011) 1120-1128.

[34] O.J. Oppezzo, Contribution of UVB radiation to bacterial inactivation by natural sunlight, Journal of Photochemistry and Photobiology B: Biology, (2012).

[35] V.G. Petin, G.P. Zhurakovskaya, L.N. Komarova, Fluence rate as a determinant of synergistic interaction under simultaneous action of UV light and mild heat in Saccharomyces cerevisiae, Journal of Photochemistry and Photobiology B: Biology, 38 (1997) 123-128.

[36] S. Pigeot-Rémy, F. Simonet, D. Atlan, J. Lazzaroni, C. Guillard, Bactericidal efficiency and mode of action: A comparative study of photochemistry and photocatalysis, Water research, 46 (2012) 32083218.

[37] M. Polo-López, P. Fernández-Ibáñez, E. Ubomba-Jaswa, C. Navntoft, I. García-Fernández, P. Dunlop, M. Schmid, J. Byrne, K.G. McGuigan, Elimination of water pathogens with solar radiation using an automated sequential batch CPC reactor, Journal of hazardous materials, 196 (2011) 16-21.

[38] M.I. Polo-López, I. García-Fernández, T. Velegraki, A. Katsoni, I. Oller, D. Mantzavinos, P. Fernández-Ibáñez, Mild solar photo-Fenton: An effective tool for the removal of Fusarium from simulated municipal effluents, Applied Catalysis B: Environmental, 111 (2012) 545-554.

[39] R.H. Reed, The inactivation of microbes by sunlight: solar disinfection as a water treatment process, Advances in applied microbiology, 54 (2004) 333-365.

[40] J. Regensburger, A. Knak, A. Felgenträger, W. Bäumler, Generation of singlet oxygen by UVBirradiation of endogenous molecules, Photodiagnosis and Photodynamic Therapy, 8 (2011) 152. 
[41] A. Rincon, C. Pulgarin, Photocatalytical inactivation of E. coli: effect of (continuous-intermittent) light intensity and of (suspended-fixed) TiO2 concentration, Applied Catalysis B: Environmental, 44 (2003) 263-284.

[42] A.-G. Rincón, C. Pulgarin, Field solar E. coli inactivation in the absence and presence of TiO2: is UV solar dose an appropriate parameter for standardization of water solar disinfection?, Solar Energy, 77 (2004a) 635-648.

[43] J. Robertson, P.K. J Robertson, L.A. Lawton, A comparison of the effectiveness of TiO2 photocatalysis and UVA photolysis for the destruction of three pathogenic micro-organisms, Journal of Photochemistry and Photobiology A: Chemistry, 175 (2005) 51-56.

[44] J. Rodríguez-Chueca, R. Mosteo, M. Ormad, J. Ovelleiro, Factorial experimental design applied to Escherichia coli disinfection by Fenton and photo-Fenton processes, Solar Energy, 86 (2012) 32603267.

[45] K.H. Schoenbach, F.E. Peterkin, R.W. Alden III, S.J. Beebe, The effect of pulsed electric fields on biological cells: experiments and applications, Plasma Science, IEEE Transactions on, 25 (1997) 284292.

[46] R.B. Setlow, The wavelengths in sunlight effective in producing skin cancer: a theoretical analysis, Proceedings of the National Academy of Sciences, 71 (1974) 3363-3366.

[47] C. Sichel, J. Blanco, S. Malato, P. Fernández-Ibáñez, Effects of experimental conditions on E. coli survival during solar photocatalytic water disinfection, Journal of Photochemistry and Photobiology A: Chemistry, 189 (2007) 239-246.

[48] L.W. Sinton, R.K. Finlay, P.A. Lynch, Sunlight inactivation of fecal bacteriophages and bacteria in sewage-polluted seawater, Applied and Environmental Microbiology, 65 (1999) 3605-3613.

[49] B. Sommer, A. Marino, Y. Solarte, M. Salas, C. Dierolf, C. Valiente, D. Mora, R. Rechsteiner, P. Setter, W. Wirojanagud, SODIS- an emerging water treatment process, AQUA(OXFORD), 46 (1997) 127-137.

[50] D. Spuhler, J.A. Rengifo-Herrera, C. Pulgarin, The effect of Fe2+, Fe3+, H202 and the photoFenton reagent at near neutral $\mathrm{pH}$ on the solar disinfection (SODIS) at low temperatures of water containing Escherichia coli K12, Applied catalysis. B, Environmental, 96 (2010) 126-141.

[51] E. Ubomba-Jaswa, C. Navntoft, M.I. Polo-López, P. Fernandez-Ibáñez, K.G. McGuigan, Solar disinfection of drinking water (SODIS): an investigation of the effect of UV-A dose on inactivation efficiency, Photochemical \& Photobiological Sciences, 8 (2009) 587-595.

[52] M. Wegelin, S. Canonica, K. Mechsner, T. Fleischmann, F. Pesaro, A. Metzler, Solar water disinfection: scope of the process and analysis of radiation experiments, Aqua, 43 (1994) 154-169.

[53] L. Rizzo, D. Sannino, V. Vaiano, O. Sacco, A. Scarpa, D. Pietrogiacomi, Effect of solar simulated $\mathrm{N}$-doped $\mathrm{TiO} 2$ photocatalysis on the inactivation and antibiotic resistance of an $\mathrm{E}$. coli strain in biologically treated urban wastewater, Applied Catalysis B: Environmental, 144 (2014) 369-378.

[54] J.J. Vélez-Colmenares, A. Acevedo, E. Nebot, Effect of recirculation and initial concentration of microorganisms on the disinfection kinetics of Escherichia coli, Desalination, 280 (2011) 20-26.

[55] A.-G. Rincón, C. Pulgarin, Bactericidal action of illuminated TiO2 on pure Escherichia coli and natural bacterial consortia: post-irradiation events in the dark and assessment of the effective disinfection time, Applied Catalysis B: Environmental, 49 (2004b) 99-112. 


\section{List of Tables}

Table 1 - Design of experiments' parameters, levels and respective units

\begin{tabular}{|c|ccc|}
\hline Parameters & \multicolumn{2}{|c|}{ Levels } & Units \\
\hline Time & 4 & $1,2,3,4$ & $\mathrm{~h}$ \\
\hline $\begin{array}{c}\text { Initial } \\
\text { Population }\end{array}$ & 4 & $10^{3}, 10^{4}, 10^{5}, 10^{6}$ & $\mathrm{CFU} / \mathrm{mL}$ \\
\hline $\begin{array}{c}\text { Temperature } \\
\text { Light Intensity }\end{array}$ & 5 & $20,30,40,50,60$ & ${ }^{\circ} \mathrm{C}$ \\
\hline
\end{tabular}




\begin{tabular}{|c|c|c|c|c|c|c|c|c|c|c|c|c|c|c|c|c|c|}
\hline$\stackrel{\Xi}{\Xi}$ & A & B & $\mathrm{C}$ & $\underset{\Xi}{\cong}$ & A & B & $\mathrm{C}$ & 君 & A & B & $\mathrm{C}$ & $\underset{\Xi}{\cong}$ & A & B & $\mathrm{C}$ & & \\
\hline 1 & 1 & 1 & 1 & 21 & 2 & 1 & 1 & 41 & 3 & 1 & 1 & 61 & 4 & 1 & 1 & & \\
\hline 2 & 1 & 1 & 2 & 22 & 2 & 1 & 2 & 42 & 3 & 1 & 2 & 62 & 4 & 1 & 2 & Factors & 3 \\
\hline 3 & 1 & 1 & 3 & 23 & 2 & 1 & 3 & 43 & 3 & 1 & 3 & 63 & 4 & 1 & 3 & Replicates & 2 \\
\hline 4 & 1 & 1 & 4 & 24 & 2 & 1 & 4 & 44 & 3 & 1 & 4 & 64 & 4 & 1 & 4 & & \\
\hline 5 & 1 & 1 & 5 & 25 & 2 & 1 & 5 & 45 & 3 & 1 & 5 & 65 & 4 & 1 & 5 & Base Runs & 80 \\
\hline 6 & 1 & 2 & 1 & 26 & 2 & 2 & 1 & 46 & 3 & 2 & 1 & 66 & 4 & 2 & 1 & Total Runs & 160 \\
\hline 7 & 1 & 2 & 2 & 27 & 2 & 2 & 2 & 47 & 3 & 2 & 2 & 67 & 4 & 2 & 2 & & \\
\hline 8 & 1 & 2 & 3 & 28 & 2 & 2 & 3 & 48 & 3 & 2 & 3 & 68 & 4 & 2 & 3 & $\begin{array}{c}\text { Base } \\
\text { Blocks }\end{array}$ & 1 \\
\hline 9 & 1 & 2 & 4 & 29 & 2 & 2 & 4 & 49 & 3 & 2 & 4 & 69 & 4 & 2 & 4 & $\begin{array}{l}\text { Total } \\
\text { Blocks }\end{array}$ & 1 \\
\hline 10 & 1 & 2 & 5 & 30 & 2 & 2 & 5 & 50 & 3 & 2 & 5 & 70 & 4 & 2 & 5 & & \\
\hline 11 & 1 & 3 & 1 & 31 & 2 & 3 & 1 & 51 & 3 & 3 & 1 & 71 & 4 & 3 & 1 & $\begin{array}{l}\text { No. of } \\
\text { levels }\end{array}$ & $A ; B ; C ;=4 ; 4 ; 5$ \\
\hline 12 & 1 & 3 & 2 & 32 & 2 & 3 & 2 & 52 & 3 & 3 & 2 & 72 & 4 & 3 & 2 & A & Time (h) \\
\hline 13 & 1 & 3 & 3 & 33 & 2 & 3 & 3 & 53 & 3 & 3 & 3 & 73 & 4 & 3 & 3 & B & $\begin{array}{l}\text { Initial Population } \\
\quad(\mathrm{CFU} / \mathrm{mL})\end{array}$ \\
\hline 14 & 1 & 3 & 4 & 34 & 2 & 3 & 4 & 54 & 3 & 3 & 4 & 74 & 4 & 3 & 4 & C & Temperature $\left({ }^{\circ} \mathrm{C}\right)$ \\
\hline 15 & 1 & 3 & 5 & 35 & 2 & 3 & 5 & 55 & 3 & 3 & 5 & 75 & 4 & 3 & 5 & & \\
\hline 16 & 1 & 4 & 1 & 36 & 2 & 4 & 1 & 56 & 3 & 4 & 1 & 76 & 4 & 4 & 1 & where: & \\
\hline 17 & 1 & 4 & 2 & 37 & 2 & 4 & 2 & 57 & 3 & 4 & 2 & 77 & 4 & 4 & 2 & A & $1,2,3,4(\mathrm{~h})$ \\
\hline 18 & 1 & 4 & 3 & 38 & 2 & 4 & 3 & 58 & 3 & 4 & 3 & 78 & 4 & 4 & 3 & B & $\begin{array}{c}10^{3}, 10^{4}, 10^{5}, 10^{6} \\
(\mathrm{CFU} / \mathrm{mL})\end{array}$ \\
\hline 19 & 1 & 4 & 4 & 39 & 2 & 4 & 4 & 59 & 3 & 4 & 4 & 79 & 4 & 4 & 4 & C & $20,30,40,50,60\left({ }^{\circ} \mathrm{C}\right)$ \\
\hline 20 & 1 & 4 & 5 & 40 & 2 & 4 & 5 & 60 & 3 & 4 & 5 & 80 & 4 & 4 & 5 & & \\
\hline
\end{tabular}


Table 3 - Percentile change of bacterial concentration after $4 \mathrm{~h}$ treatment in absence of solar light

\begin{tabular}{|l|r|r|r|r|}
\hline & $\mathbf{1 0}^{\mathbf{3}}$ & $\mathbf{1 0}^{\mathbf{4}}$ & $\mathbf{1 0}^{\mathbf{5}}$ & $\mathbf{1 0}^{\mathbf{6}}$ \\
\hline $\mathbf{2 0 ^ { \circ } \mathbf { C }}$ & 10 & 2 & 8 & 5 \\
\hline $\mathbf{3 0} \mathbf{0}^{\circ} \mathbf{C}$ & 10 & 24 & 30 & 50 \\
\hline $\mathbf{4 0}^{\circ} \mathbf{C}$ & 20 & 50 & 50 & 70 \\
\hline $\mathbf{5 0 ^ { \circ } \mathbf { C }}$ & -100 & -96.8 & -95.2 & -95 \\
\hline $\mathbf{6 0}^{\circ} \mathbf{C}$ & -100 & -100 & -100 & -100 \\
\hline
\end{tabular}

Table 4 - Percentile removal of bacterial concentration after $4 \mathrm{~h}$ treatment under $800 \mathrm{~W} / \mathrm{m}^{2}$ light.

\begin{tabular}{|r|r|r|r|r|} 
& $\mathbf{1 0}^{\mathbf{3}}$ & $\mathbf{1 0}^{\mathbf{4}}$ & $\mathbf{1 0}^{\mathbf{5}}$ & $\mathbf{1 0}^{\mathbf{6}}$ \\
\hline $\mathbf{2 0 ^ { \circ } \mathbf { C }}$ & 90.0 & 88.0 & 87.5 & 93.3 \\
\hline $\mathbf{3 0}{ }^{\circ} \mathbf{C}$ & 87.0 & 86.7 & 68.8 & 93.3 \\
\hline $\mathbf{4 0}^{\circ} \mathbf{C}$ & 47.4 & 30.0 & 15.8 & 25.0 \\
\hline $\mathbf{5 0}$ & 100.0 & 100.0 & 99.9 & 99.9 \\
\hline $\mathbf{6 0}^{\circ} \mathbf{C}$ & 100.0 & 100.0 & 100.0 & 100.0 \\
\hline
\end{tabular}


Table 5 - ANOVA table for each intensity level

\begin{tabular}{|c|c|c|c|c|c|c|c|c|c|c|c|c|c|c|c|c|}
\hline $\begin{array}{c}\text { Process } \\
\text { Efficiency }\end{array}$ & $D F$ & $\begin{array}{l}\text { Intensity } \\
0 \mathrm{~W} / \mathrm{m}^{2}\end{array}$ & SS & MS & $F$ & $P$ & $\begin{array}{l}\text { Intensity } \\
800 \mathrm{~W} / \mathrm{m}^{2}\end{array}$ & SS & $M S$ & $F$ & $P$ & $\frac{\text { Intensity }}{1200 \mathrm{~W} / \mathrm{m}^{2}}$ & SS & $M S$ & $F$ & $P$ \\
\hline$t$ & 3 & & 1662 & 554 & 2.82 & 0.045 & & 7710.6 & 2570.2 & 13.41 & 0 & & 29034.5 & 9678.2 & 31.09 & 0 \\
\hline$T$ & 4 & & 147130 & 36783 & 187.52 & 0 & & 44260.2 & 11065 & 57.72 & 0 & & 15212.1 & 3803 & 12.22 & 0 \\
\hline C & 3 & & 772 & 257 & 1.31 & 0.278 & & 5106.4 & 1702.1 & 8.88 & 0.2 & & 549 & 183 & 0.59 & 0.625 \\
\hline Error & 69 & & 13534 & 196 & & & & 13228.1 & 191.7 & & & & 21480.2 & 311.3 & & \\
\hline Total & 79 & & 163098 & & & & & 70305.3 & & & & & 66275.9 & & & \\
\hline
\end{tabular}


Table 6 -

Summary of the

Coefficients

Model 1

Constant

t

C

I

$t^{*} \mathrm{C}$

t*T

t*I

$\mathbf{T}^{*} \mathbf{C}$

T*I

C*I

t*T*C

$\mathbf{t}^{*} \mathbf{T}^{*} \mathbf{I}$

$\mathbf{T} * \mathbf{C} * \mathbf{I}$

t*T*C*I

Error

Total

$\begin{array}{cccccc}\text { Model } \mathbf{2}\left(\mathbf{\leq 4 0} \mathbf{0}^{\circ} \mathbf{C}\right) & \text { Coef } & \text { SE } & \mathbf{T} & \mathbf{P} & \mathbf{D F} \\ \mathbf{C o n s t a n t} & 4.2149 & 7.7882 & 0.5420 & 0.5890 & \\ \mathbf{t} & 10.4743 & 1.4945 & 7.0086 & 0.0000 \\ \mathbf{T} & -0.8980 & 0.2046 & -4.3882 & 0.0000 \\ \mathbf{C} & 0.0000 & 0.0000 & -1.0770 & 0.2830 \\ \mathbf{I} & 0.0588 & 0.0034 & 17.5428 & 0.0000 \\ \text { Error } & & & & & \\ \text { Total } & & & & \end{array}$

Model $2\left(>40^{\circ} \mathrm{C}\right)$

Constant

t

T

C

I

Total

$\begin{array}{llll}-8.4277 & 7.5979 & -1.1092 & 0.2690\end{array}$

$\begin{array}{llll}1.7565 & 0.5057 & 3.4736 & 0.0010\end{array}$

0.0000

0.0000

$-0.6980$

0.4860

0.0178

0.0000
0.2726

$0.0000 \quad 0.4976$

0.0355

0.0085

0.0000

0.0000

$-0.000$

0.0000

0.0000

0.0006

0.0000

0.0000

$-0.0007$

0.0000

0.0002

0.0000

1.5023

4.1911

0.4779

$-0.1257$

0.2742

$-0.2630$

$-3.1913$

$-0.5146$

.4590

0.6190
0.1340

0.0000

0.6330

0.9000

0.7840

0.7930

0.0020

0.6070

0.7690

$\begin{array}{lll}15.4915 & 0.0000 \\ -0.7650 & 0.4460\end{array}$

$\begin{array}{cc}-0.7650 & 0.4460 \\ 5.7425 & 0.0000\end{array}$
Analysis of Variance

\begin{tabular}{lllll|l} 
Coef & SE & T & P & DF & Seq SS
\end{tabular}

\begin{tabular}{lllll|c}
-41.6006 & 21.2256 & -1.9599 & 0.0510 & 14.0 & 250386.0
\end{tabular}

1.0

28413.0

Adj SS

Adj MS

83168.0

734.0

17884.7

F

29.9798

1.2304

7198.0

7197.9

12.0658

0.4872

84823.0

328.0

290.6

0.5503

656.0

1801.0

148.0

1346.0

10479.0

147.7

1346.3

0.2476

2.2568

26.0

136.0

136.2

37360.0

83.0

15.0

6122.0

107.0

51.0

134225.0 384611.0

DF

4.0

Seq SS
151682.0

151682.0
19748.0

19748.0
7742.0

466.0

123726.0

55882.0 $143.0 \quad 207564.0$

$\begin{array}{lll}9.4 & 0.0158 & 0.9001\end{array}$

$\begin{array}{llll}45.0 & 44.8 & 0.0752 & 0.7842\end{array}$

$\begin{array}{llll}41.0 & 41.2 & 0.0691 & 0.7928\end{array}$

$\begin{array}{llll}6075.0 & 6075.4 & 10.1841 & 0.0016\end{array}$

$\begin{array}{llll}158.0 & 158.0 & 0.2648 & 0.6073\end{array}$

$\begin{array}{llll}51.0 & 51.4 & 0.0862 & 0.7693\end{array}$

$134225.0 \quad 596.6$

Adj SS Adj MS F

F

94.3

$19748.0 \quad 19748.0 \quad 49.1$

$\begin{array}{lll}7742.0 & 7742.0 & 19.3\end{array}$

$\begin{array}{lll}466.0 & 466.0 & 1.2\end{array}$

$\begin{array}{lll}123726.0 & 123726.0 \quad 307.8\end{array}$

$55882.0 \quad 402.0$

Seq SS

Adj SS Adj MS F

$\begin{array}{ccc}13219.0 & 13219.0 & 27.5\end{array}$

$\begin{array}{lll}115385.0 & 115385.0 & 240.0\end{array}$

$\begin{array}{cccc}281.0 & 281.0 & 281.0 & 0.6 \\ 15855.0 & 15855.0 & 15855.0 & 33.0\end{array}$

$66831.0 \quad 481.0$

211571.0

143.0

33.0

P Summary of Model

$0.0 \quad \mathrm{~S}=20.0507$

$0.0 \quad$ PRESS $=60045.2$

$0.0 \quad \mathrm{R}-\mathrm{Sq}=73.08 \%$

$\begin{array}{ll}0.0 & \mathrm{R}-\mathrm{Sq}=73.08 \% \\ 0.3 & \mathrm{R}-\mathrm{Sq}(\mathrm{adj})=72.30 \%\end{array}$

$\begin{array}{ll}0.3 & \mathrm{R}-\mathrm{Sq}(\mathrm{adj})=72.30 \% \\ 0.0 & \mathrm{R}-\mathrm{Sq}(\text { pred })=71.07 \%\end{array}$

P Summary of Model

$0.0 \quad \mathrm{~S}=21.9270$

$0.0 \quad$ PRESS $=71869.3$

$\begin{array}{ll}0.0 & \text { PRESS }=71869 \\ 0.0 & \mathrm{R}-\mathrm{Sq}=68.41 \%\end{array}$

$0.4 \quad \mathrm{R}-\mathrm{Sq}(\operatorname{adj})=67.50 \%$

$0.0 \quad \mathrm{R}-\mathrm{Sq}($ pred $)=66.03 \%$ 


\section{List of Figures}
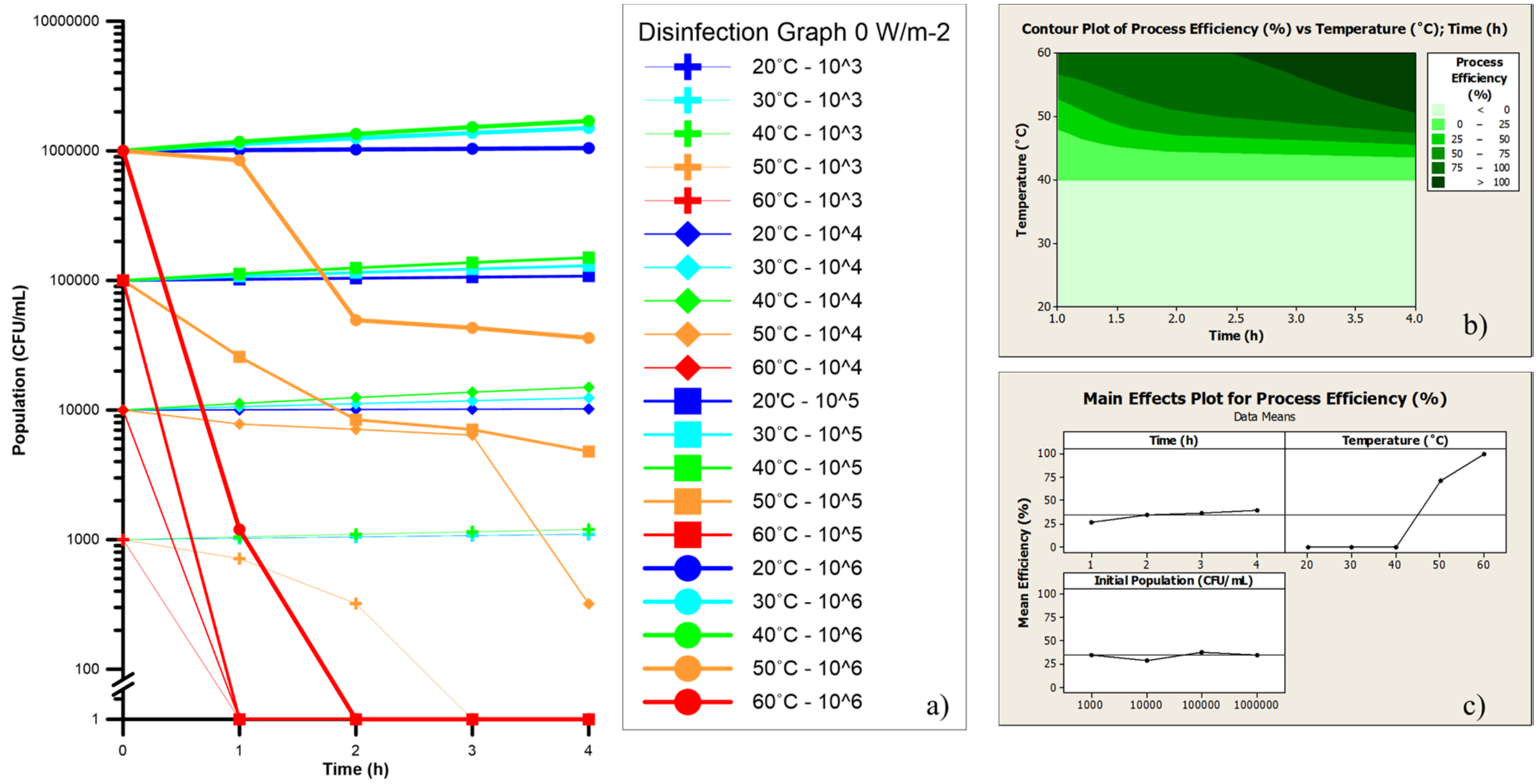

Figure 1 - Main results of non-irradiation experiments for synthetic secondary effluent at different temperatures and initial E. coli populations. (a) Disinfection kinetic curves. (b) Contour plot of process efficiency vs. temperature and time. (c) Main effects plot (control variable: Process Efficiency) 


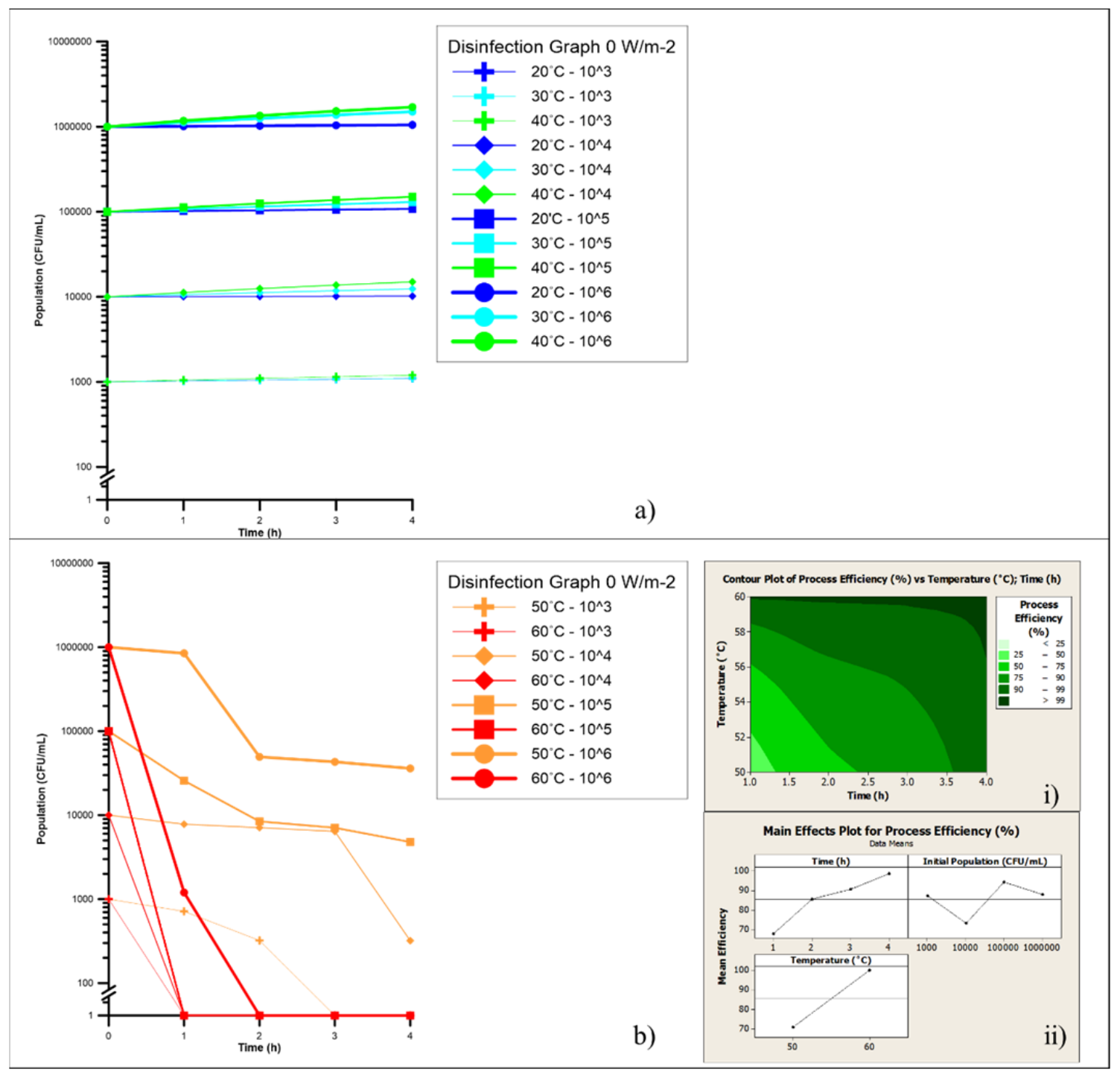

Figure 2 - Main results of non-irradiation experiments for synthetic secondary effluent at different temperatures and initial E. coli populations. (a) 20-40 ${ }^{\circ} \mathrm{C}$ kinetic curves. (b) 50-60 ${ }^{\circ} \mathrm{C}$ kinetic curves. $b$-i) Contour plot of the changes in process efficiency vs. temperature and time from 50-60 ${ }^{\circ} \mathrm{C}$. b-ii) Main effects plot for temperatures $50-60{ }^{\circ} \mathrm{C}$ (control variable: Process Efficiency) 

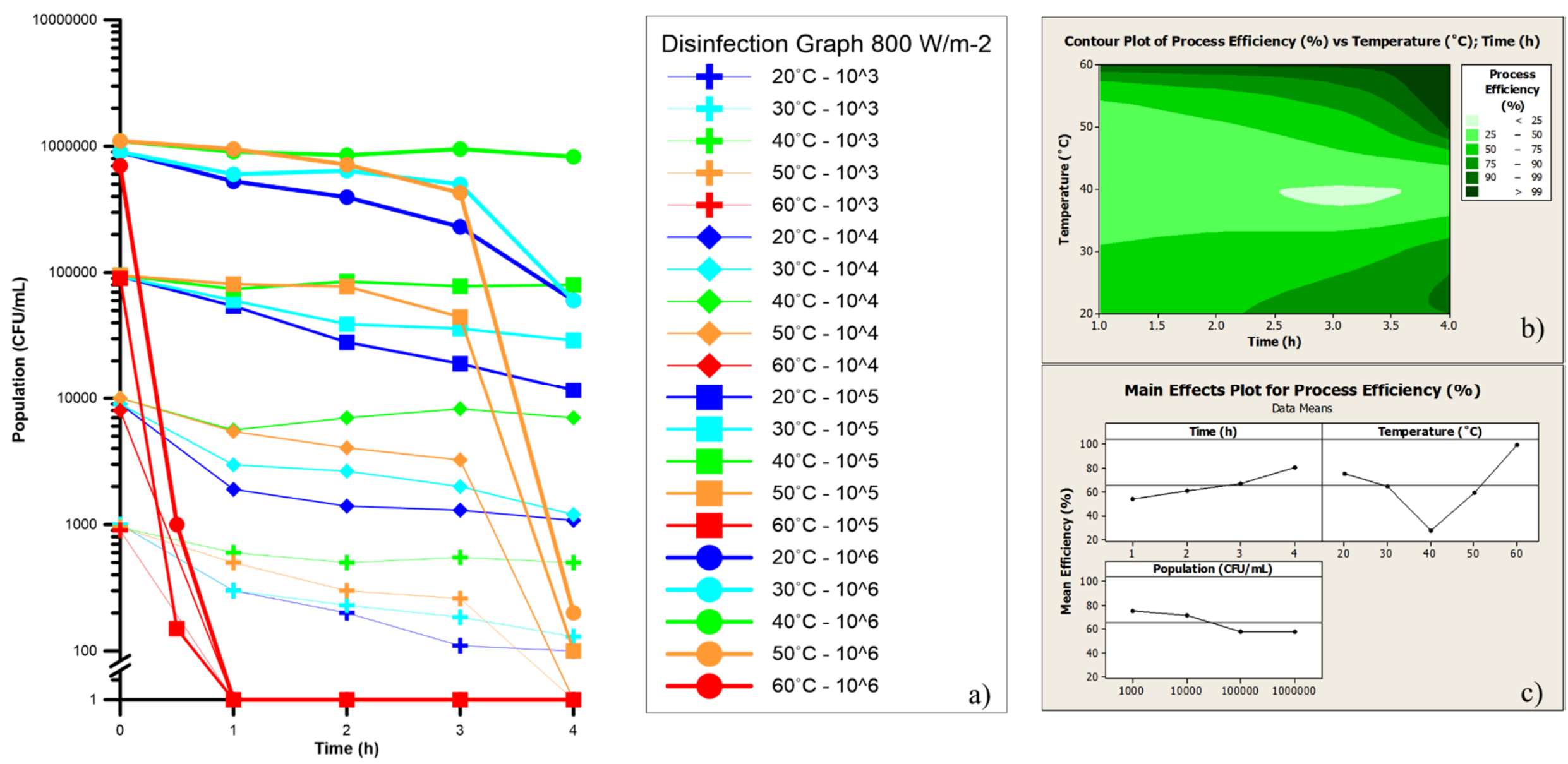

Figure 3-Main results of $800 \mathrm{~W} / \mathrm{m}^{2}$ experiments for synthetic secondary effluent at different temperatures and initial E. coli populations. (a) Disinfection kinetic curves. (b) Contour plot of process efficiency vs. temperature and time. (c) Main effects plot (control variable: Process Efficiency) 

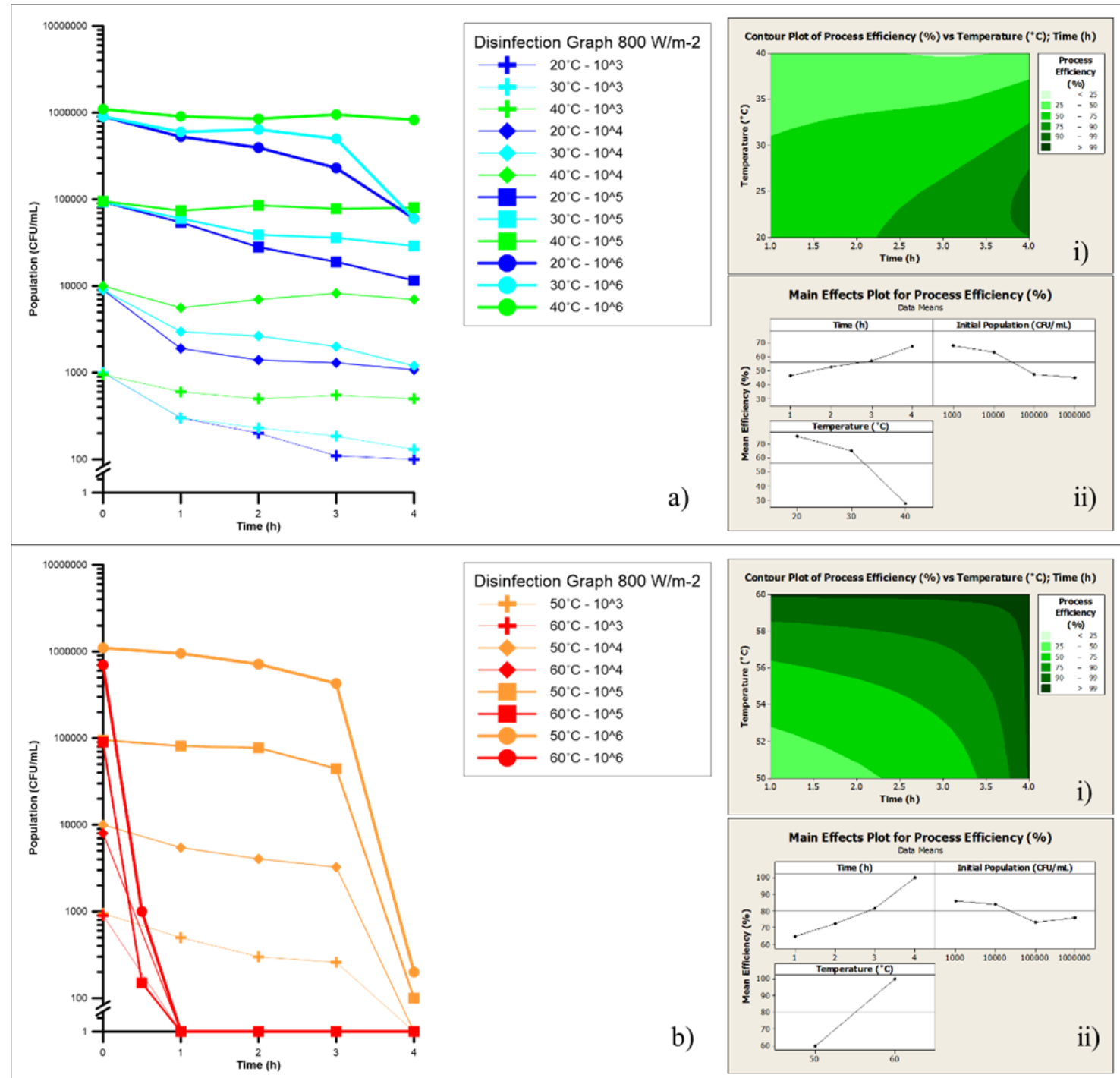

Main Effects Plot for Process Efficiency (\%)

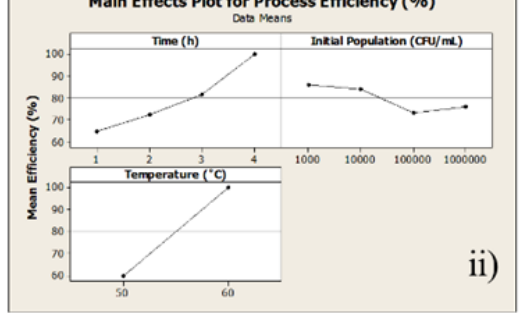

Figure 4-Main results of $800 \mathrm{~W} / \mathrm{m}^{2}$ experiments for synthetic secondary effluent at different temperatures and initial E. coli populations. (a) 20-40 ${ }^{\circ} \mathrm{C}$ Disinfection kinetic curves, a-i) 20-40 ${ }^{\circ} \mathrm{C}$ contour plot of process efficiency vs. temperature and time, a-ii) 20-40 ${ }^{\circ} \mathrm{C}$ Main effects plot (control variable: Process Efficiency). (b) 50-60 ${ }^{\circ} \mathrm{C}$ Disinfection kinetic curves, b-i) 50-60 ${ }^{\circ} \mathrm{C}$ contour plot of process efficiency vs. temperature and time, b-ii) 50-60 ${ }^{\circ} \mathrm{C}$ Main effects plot (control variable: Process Efficiency). 

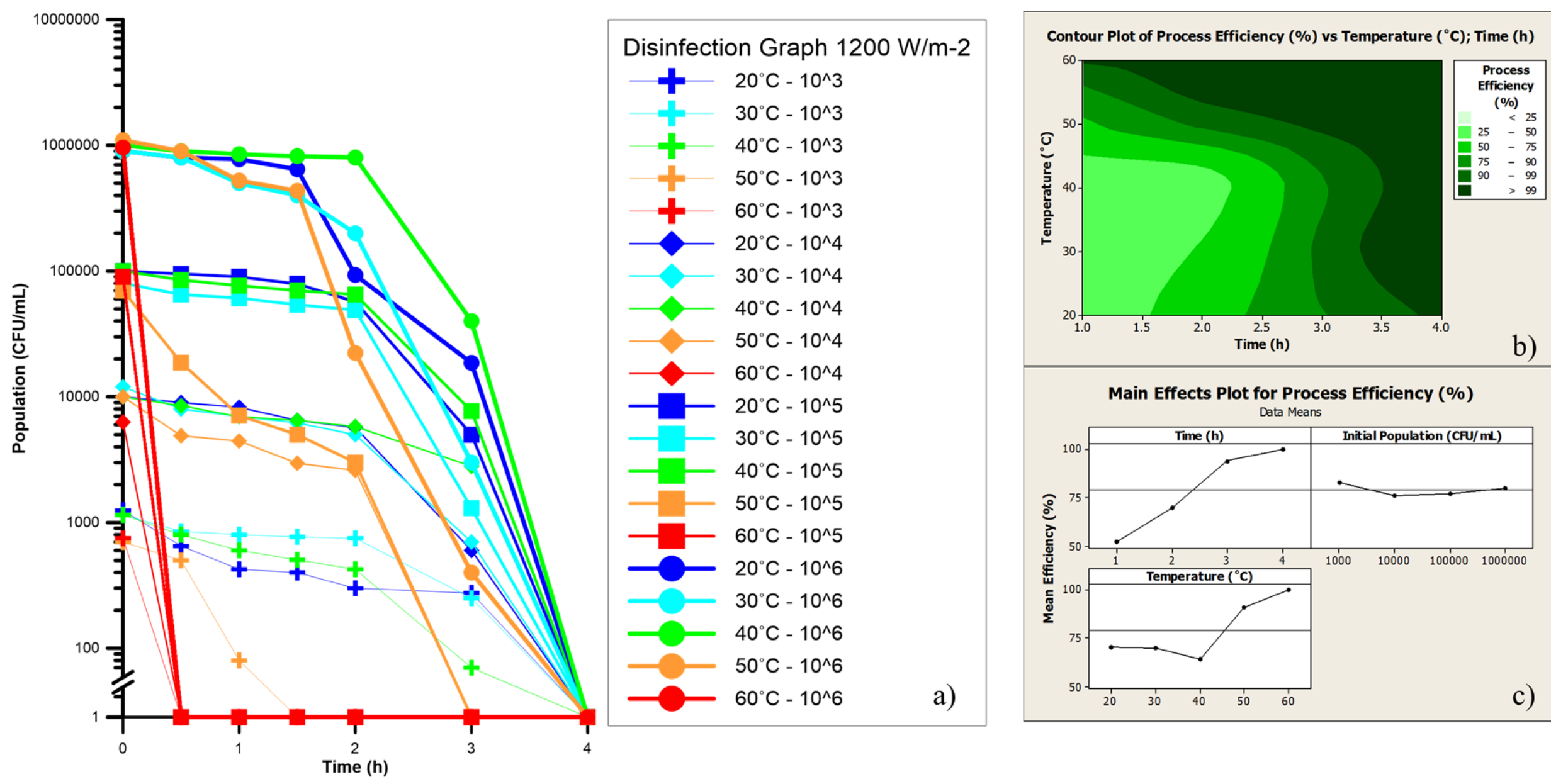

Figure 5-Main results of $1200 \mathrm{~W} / \mathrm{m}^{2}$ experiments for synthetic secondary effluent at different temperatures and initial E. coli populations. (a) Disinfection kinetic curves. (b) Contour plot of process efficiency vs. temperature and time. (c) Main effects plot (control variable: Process Efficiency) 

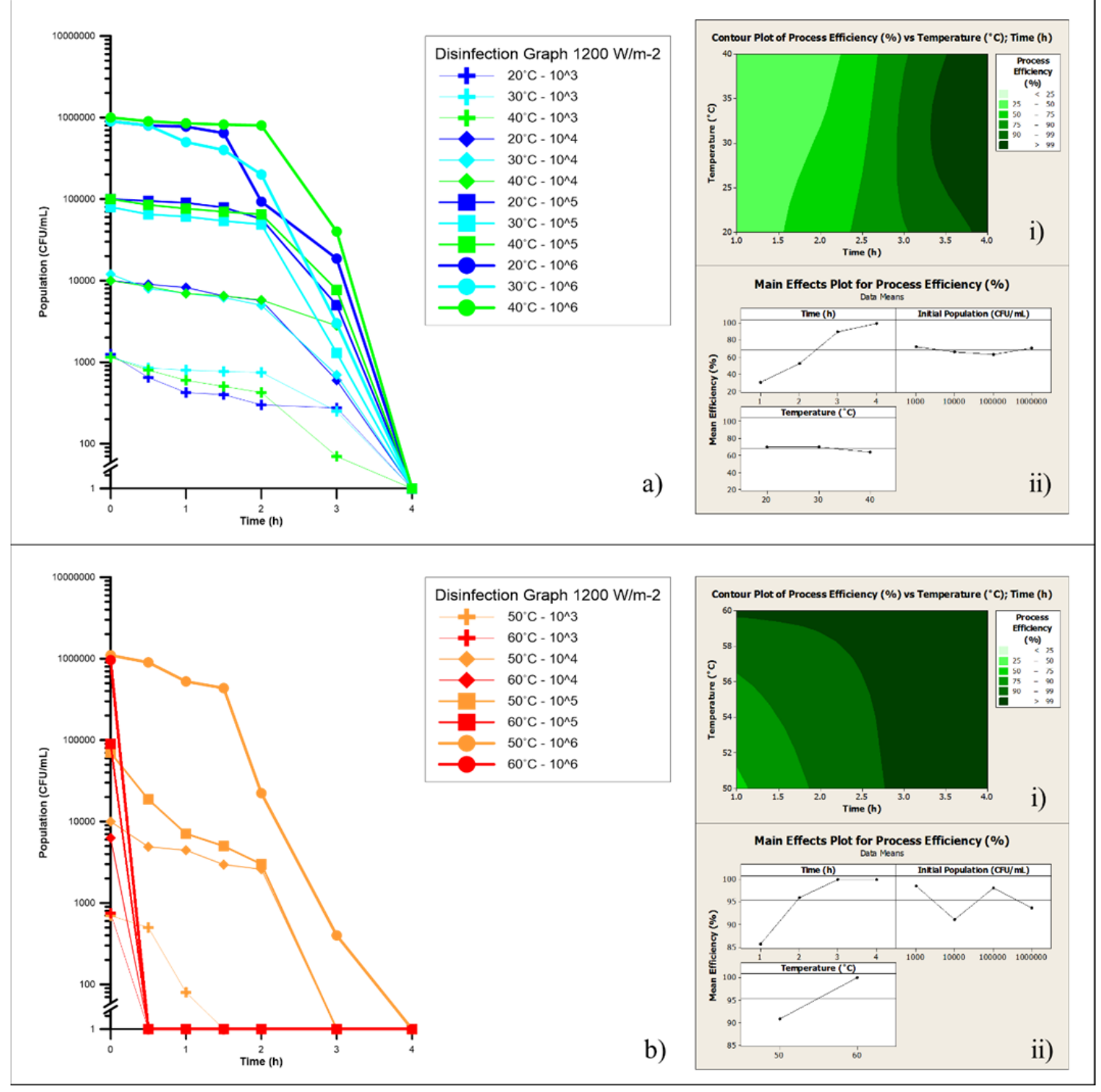

Figure 6 - Main results of $1200 \mathrm{~W} / \mathrm{m}^{2}$ experiments for synthetic secondary effluent at different temperatures and initial E. coli populations. (a) 20-40 ${ }^{\circ} \mathrm{C}$ Disinfection kinetic curves, a-i) 20$40{ }^{\circ} \mathrm{C}$ contour plot of process efficiency vs. temperature and time, a-ii) 20-40 ${ }^{\circ} \mathrm{C}$ Main effects plot (control variable: Process Efficiency). (b) 50-60 ${ }^{\circ} \mathrm{C}$ Disinfection kinetic curves, b-i) 50-60 ${ }^{\circ} \mathrm{C}$ contour plot of process efficiency vs. temperature and time, b-ii) 50-60 ${ }^{\circ} \mathrm{C}$ Main effects plot (control variable: Process Efficiency). 
Comparison between experimental data and model with interactions
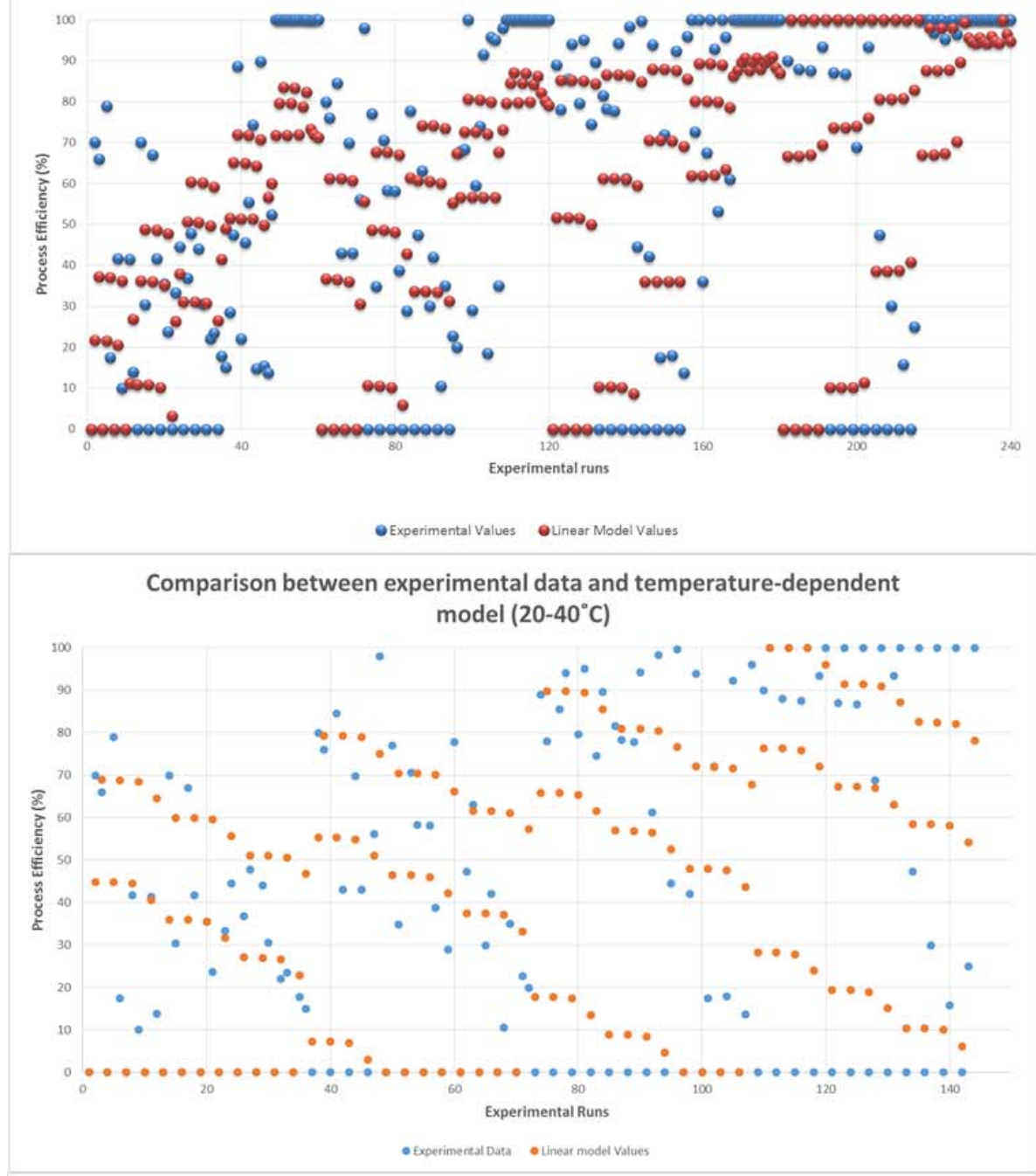

Comparison between experimental data and temperature-dependent model $\left(40-60^{\circ} \mathrm{C}\right)$

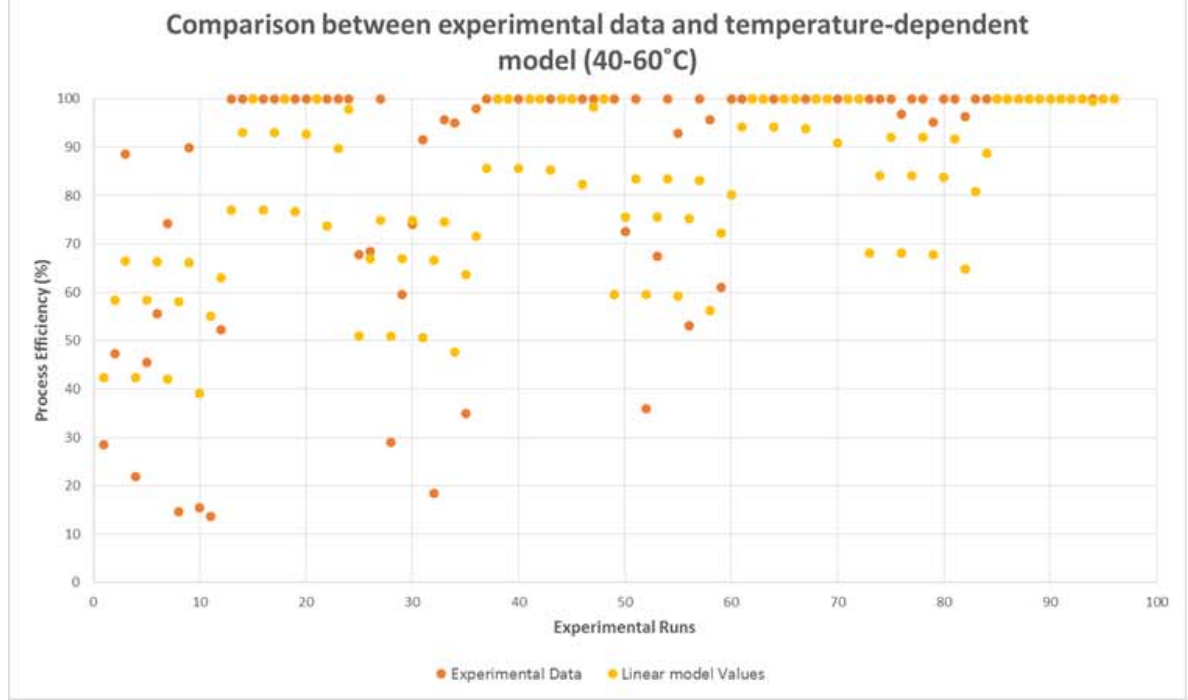
dependent model $\left(20-40^{\circ} \mathrm{C}\right)$. (c) Temperature dependent model $\left(40-60^{\circ} \mathrm{C}\right)$. 